\title{
Consent, Legitimation, and Dysphoria
}

Robin West

Georgetown University Law Center, west@law.georgetown.edu

This paper can be downloaded free of charge from:

https://scholarship.law.georgetown.edu/facpub/2290

https://ssrn.com/abstract=3636497

Modern Law Review, Vol. 83, Issue 1, Pp. 1-34.

This open-access article is brought to you by the Georgetown Law Library. Posted with permission of the author. Follow this and additional works at: https://scholarship.law.georgetown.edu/facpub

Part of the Law and Society Commons, and the Sexuality and the Law Commons 


\section{Introduction}

\section{Consent, Legitimation, and Dysphoria}

It is now a truism that many of the legal obligations of individuals in western legal systems - and particularly those systems which derive from the common law -- have moved decisively "from status to contract" over the last two hundred years, by which is meant, generally, that while an individual's rights and responsibilities were once a function of his or her status stemming from the circumstances of birth or family position - her status as slave, servant, master, husband, wife, first born, later-born, daughter, or son -- today, the legal rights and responsibilities an individual possesses are largely a function of to what he or she has contractually agreed to do or refrain from doing. ${ }^{1}$ We contract into our rights and responsibilities, we are not legally assigned them by virtue of the accidents of our birth. This movement, famously heralded by Henry Maine in the middle of the nineteenth century, has been an even more striking and prominent feature of twentieth and twenty first century law. Across a sizeable number of both private and public fields of law -- including family law, tort law, employment law, parts of fiduciary law, criminal law, constitutional law and civil procedure -contract principles, contract law, and of course ultimately contracts themselves are displacing other, more regulative, and arguably more coercive, legal norms. Each such developmenteach movement from status to contract -- over the last century and a half, has attracted celebrants, but also scores of critics. ${ }^{2}$

\footnotetext{
${ }^{1}$ HenRy MaINe, ANCIENT LAW 168 (1861).

${ }^{2}$ For discussion and critique of the growing role of contract in family law, see Jana Singer, The Privatization of Family Law, 1992 WIS. L. REV. 1443 (1992); Jana Singer, Legal Regulation of Marriage: From Contract to Status -

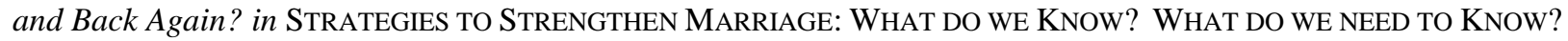
(The Family Impact Seminar, June 1998).

The displacement of large swaths of employment law with contract law, through mandatory arbitration clauses, mandatory waivers, and other devices, has generated a large and largely critical literature. See, e.g., Joseph Grodin, Arbitration of Employment Discrimination Claims: Doctrine and Policy in the Wake of Gilmer, 14 HOFSTRA LAB. \& EMP. L. J. 1 (1996); Penelope Hopper, Mandatory Arbitration and Title VII: Can Employees Ever See Their Rights Vindicated Through Statutory Causes of Action, 1995 J. DISP. RESOL. 315 (1995); Stephen Plass, Privatizing Antidiscrimination Law with Arbitration: The Title VII Proof Problem, 68 MonT. L. REV. 151 (2007); Harry Edwards, Where are We Heading with Mandatory Arbitration of Statutory Claims in Employment, 16 GA. ST. U. L. REV. 293 (1999-2000). The lack of coverage under Title VII for independent contractors in particular has generated an extensive and critical literature, much of it aimed at formulating ways to protect independent contractors from discrimination, given their exclusion from Title VII. In addition to the pieces noted above see, e.g., Lewis Maltby \& David Yamata, Beyond Economic Realities: The Case for Amending Federal Employment Discrimination Laws to Include Independent Contractors, 38 B.C. L. REV. 239 (1996-1997); Daniel Tarantolo, From Employment to Contract: Section 1981 and Antidiscrimination Law for the Independent Contractor Workforce, 116 YALE L.J. 170 (2006-2007); Brishen Rogers, The Social Costs of Uber, 82 U. CHI. L. REV. DiALOGUE 85 (2015-2016); Charlotte Alexander, Misclassification and Antidiscrimination, an Empirical Analysis, 101 MiNN. L. R. 907 (2017); Michael C. Harper, Explaining the Blurred Line Between Employment and Independent Contracting, JOTWELL (September 16, 2015) reviewing Tomassetti,), https://worklaw.jotwell.com/explaining-the-blurred-line-between-employmentand-independent-contracting/ and Julia Tomassetti, The Contracting/Producing Ambiguity and the Collapse of the Means/Ends Distinction in Employment, 66 S.C. L. REV. 315 (2014).

The effect of mandatory arbitration clauses on sexual harassment in the workplace is now a subject of public discourse. For an early analysis of the problems with the role of contract in this area see Mollie H. Bowers \& E. Patrick McDermott, Sexual Harassment in the Workplace: How Arbitrators Decide, 48 CLEV. ST. L. REV. 439 (2000); Equally important, however, is the effect of mandatory arbitration clauses on other forms of discrimination, as well as all other affected employment rights. For discussions of the broader perspective, see, Katherine Stone, Mandatory Arbitration of Individual Employment Rights: The Yellow Dog Contract of the 1990s, 73 DENV. U. L. REV. 1017 (1995-1996); Katherine Eddy, To Every Remedy a Wrong: The Confounding of Civil Liberties through Mandatory Arbitration Clauses in Employment Contracts, 52 HASTINGS L.J. 771 (2000-2001); David Schwartz,
} 
Albeit less noted, a parallel development in legal consciousness may have accompanied the doctrinal shift from status to contract. As "status" has given way to "contract," as Maine both observed and predicted, so the appreciation and respect once accorded the generative power of the "law" that once created those statuses, may be steadily giving way to that of the individual acts of "consent" that generate - at least in theory - all of those contractual obligations. Thus, as law gives way to consent as the generative source of our rights and responsibilities, so the felt moral authority of law may be ceding ground, in turn, to the felt moral authority of consent. Thus: the shift in consciousness. Today, it is often the act of an individual proffering his or her consent, rather than the enactment of a law by a representative governmental body, which garners our respect and deference. Individual consent, rather than democratic law, in effect, is emerging as the main source of legitimate authority.

We can see the shift away from the authority of law, and to the authority of consent, in

Mandatory Arbitration and Fairness, 84 Notre DAME L. REV. 1247 (2008-2009). For advocacy of the displacement of antidiscrimination law with contract law, see GARY BECKER, THE ECONOMICS OF DISCRIMINATION 57-58 (2d ed. 1971) Epstein's contribution in Richard A. Epstein \& Erwin Chemerinsky, Should Title VII of the Civil Rights Act of 1964 be Repealed?, 2 S. CAL. INTERDISC. L. J. 349 (1993) and Richard Epstein, FORBIDDEN GROUNDS: THE CASE AGAINST EMPLOYMENT DisCRIMINATION LAWS (1992).

For discussion and criticism of the degree to which contract has displaced constitutional norms outside of employment law, such as in criminal and civil procedure, see, e.g., Stephen J. Ware, Mandatory Arbitration: Arbitration Clauses, Jury-Waiver Clauses, and Other Contractual Waivers of Constitutional Rights, 67 L. \& Contemp. PRoB. 167, 170 (2004); Jean R. Sternlight, Mandatory Binding Arbitration and the Demise of the Seventh Amendment Right to a Jury Trial, 16 OHIO ST. J. DisP. RESOL. 669, 678 (2001); Amanda Szuch, Reconsidering Contractual Waivers of the Right to a Jury Trial in Federal Court, 79 U. CIN. L. REV. (2011); Senator Russell Feingold, Mandatory Arbitration: What Process is Due, 39 HARV. J. LEGIS. 281 (2002). For classic discussions of the still worsening problem of plea agreements displacing due process rights, see John Langbein, On the Myth of Written Constitutions: The Disappearance of Criminal Jury Trial, 15 HARV. J. L. \& PUB. POL'Y 119 (1992); John Langbein, Torture and Plea Bargaining, 46 CHI. L. REV. 3 (1978); Stephanos Bibas, Plea Bargaining Outside the Shadow of the Law, 117 HARV. L. REV. 2463 (2004) and Stephanos Bibas, Regulating the Plea-Bargaining Market: From Caveat Emptor to Consumer Protection, 99 CALIF. L. REV. 1117 (2011). For an early near-canonical discussion of the general tension between a contract and civil rights sensibility see PATRICIA WILLIAMS, THE ALCHEMY OF RACE AND RIGHTS at 98-130 (1992), and

For a discussion and partial critique of the tendency to see fiduciary relationships and obligations as a species of contractual relationships, see Gregory Klass, What if Fiduciary Obligations are Like Contractual Ones? in Contract, StatuS, AND FiduCiary LaW 93-117 (Paul B. Miller \& Andrew S. Gold eds., 2016). For a defense of the view that fiduciary obligations are nothing but contractual obligations, see Frank H. Easterbrook \& Daniel R. Fischel, Contract and Fiduciary Duty, 36 J. L. \& ECON. 425 (1993). See also Victor Brudney, Contract and Fiduciary Duty in Corporate Law, 38 B.C. L. REV. 595 (1997).

And finally, for discussion of the displacement of tort law by contract, See Scott J. Burnham, Are You Free to Contract Away Your Negligence Claim?, 89 CHI.-KENT L. REV. 379 (2014). For an early defense of the proposition that one should be free to subject tort to contractual limits, see RICHARD POSNER, ECONOMIC ANALYSIS OF LAW 158 (1977). For an argument that permitting contractual waivers of the right to sue for malpractice would reduce medical costs and not result in an increase of malpractice, see RICHARD H. THALER AND CASS SUNSTEIN, NUDGE: IMPROVIng DECISIONS ABOUT HEALTH, WeAlTh AND HAPPINESS, 4-6 (2008). For a response, see Tom Baker \& Timothy Lytton, Allowing Patients to Waive the Right to Sue for Medical Malpractice: A Response to Thaler and Sunstein, 104 NW. U. L. REV. 233 (2010). The law of informed consent - a hybrid of tort and contract - has increasingly displaced traditional conceptions of malpractice, in health care law. For an overall discussion and critique of the law of informed consent in this and other doctrinal areas, see Alan Schwartz et al., Encouraging Contractual Alternatives to Tort, in 2 AMERICAN LAW INSTITUTE, COMPENSATION AND LIABILITY FOR Product Related InJURIES: Proposed FinAl RePORT, Council Draft \#1, 581 (1990). See generally, PAUl H. Rubin, TORT ReForm By CONTRACt (1993); George L. Priest, A Theory of the Consumer Product Warranty, 90 YALE L. J. 1297, 1347-49 (1981). 
large swaths of social and legal life, ${ }^{3}$ but nowhere, I believe, is this quasi-Mainean shift from law

${ }^{3}$ For a powerful and seminal philosophical treatment of the "magical" "transformative" power of consent to, inter alia, "create and destroy obligations in the blink of an eye," and the way that it "thus constitutes a normative power that allows agents to change their moral landscape, to alter others' moral legacies, and to author moral laws by will alone," see Heidi Hurd, The Normative Force of Consent, collected in the Routledge Handbook on The Ethics of Consent, Peter Schaber ed. (Routledge Press, 2016); Heidi M. Hurd, The Moral Magic of Consent, 2 LEGAL THEORY 121, (1996); Available at SSRN: https://ssrn.com/abstract=2643657. See also Larry Alexander, The MoralMagic ofConsent (ii) 2 LEGAL THEORY 165, 166-67 (1996).

For more recent treatments of the role of consent in sexual ethics and in sexual assault, see the essays in THE Ethics of CONSENT: THEORY AND PRACTICE (Franklin G. Miller \& Alan Wertheimer eds., 2010); Alan Wertheimer, Consent to SEXuAl Relations (2003); Peter Westen, THE Logic of Consent: THE Diversity AND DECEPTIVENESS OF CONSENT AS A DEFENSE TO CRIMINAL CONDUCT (2004). For critical commentary, particularly in the context of criminal law, see Vera Bergelson, The Meaning of Consent, 12 OHIO ST. J. OF CRIM. LAW 171 (2014) and Robin West, Sex, Consent and Law, in Wertheimer AND Miller, ETHICS OF CONSENT, supra. See also Vera Bergelson, The Right to Be Hurt: Testing the Boundaries of Consent, 75 GEO. WASH. L. REV. 165, 203 (2007). For a critique related to the one presented here (and which was published after this essay was in press) see Joseph Fischel, SCREW CONSENT: A BETTER POLITICS OF SEXUAL Justice (2019).

For discussions of the growing dominance of consent in contract law, and its displacement of other, and older, understandings of the basis of contractual obligations, see e.g., Randy Barnett, Contract is Not Promise; Contract is Consent, 45 Suffolk L. Rev. 647 (2012) and Randy Barnett, A Consent Theory of Contract, 86 Colum. L. ReV. 269 (1986). See also Schuck, Rethinking Informed Consent, supra note 2, at 956-59 for an insightful discussion of the role of consent in contract and tort.

It is not hard to see the intuitive appeal of the move from law to consent as the basis for rights and responsibilities. Re-consider in this light Ronald Dworkin's influential definition of liberalism, penned in the 1980s, as requiring a principled commitment to both some version of individualism and some commitment to equality. Ronald Dworkin, Why Liberals Should Care About Equality, in RONALD DwORKIN, A MATTER OF PRINCIPLE (1985). Notice how well the movement from law to consent fits that Dworkinian mimima. First, consent, much better than law, clearly serves the ends of individualism. Individuals' obligations, post status-to-contract and post law-to-consent evolutions, are a function of the contracts and contract terms to which they freely and individually consent, rather than a function of a status conferred by law and endured by virtue of circumstances of birth. And, "consent" is individualizing, while "law" rests on generalities. Hence the rights and obligations to which acts of consent give rise are conducive to individual conceptions of flourishing, each derived according to each individual's own light. Just as clearly, the strike against caste, and caste systems of governance, occasioned by both movements is also profoundly egalitarian: Caste governance and the beliefs that support it are at the heart of the dehumanization and degradation of the slave, the servant, the wife, the mother, the harlot, the daughter, the lesser-born and the laterborn, the commoner, the serf, the untouchable, and so on. The movement from status to contract is thus egalitarian, to the considerable degree that statuses themselves rest on inegalitarian rankings of human beings. Finally, the movement from law to consent has a universalist - and thereby liberalizing and equalizing -- dimension as well. As Maine intimates in his famous passage, the "consent" of anyone capable of giving it has equal effect, while "law," virtually by definition proceeds by categorization, creating legal distinctions between groups of people: between criminals and non-criminals, felons and law-abiders, taxpayers and non-taxpayers, renters and buyers, sellers and manufacturers, and so on. When we are ruled by law, we are members of these various state and law-defined groups and our rights and responsibilities are defined accordingly and differentially. Under a regime of consent, by contrast, we are all, simply, contractors, and we enjoy that minimal status only to whatever degree we have consented to it. Our rights and responsibilities are defined by each of us, but they are also defined by all of us, and in the same way. Thus, contract law's formal equality. The relation between the movement from law to consent, as well as from status to contract, on the one hand, and the rise of liberalism and then neoliberalism on the other, is quite clear. 
to consent as the necessary and sufficient grounds of the legitimacy of our social roles and responsibilities more vividly manifested than in the mid-to-late twentieth century's twinned feminist movements, spanning a number of areas of law, for women's civil rights to reproductive and sexual autonomy. These reproductive and sexual civil rights, unlike other United States twentieth century civil rights, were decidedly not won either through expansive readings of the antidiscrimination norm, creative interpretations of the constitutional ideal of either substantive or formal equality, expansions of the fourteenth amendment's mandate of equal protection of the laws, or through statutory innovations guaranteeing equal participation in, access to, or enjoyment of some aspect of social life, either sexual, reproductive, or otherwise. They were, rather, won through either legislative, constitutional or litigative achievements that rested heavily - and sometimes entirely - on the quasi-Mainean claim that to be recognized as fully human requires that one have the power to consent to one's legal rights and responsibilities in intimate and familial life, no less than in public life. Thus, the movement from the authority of law to the authority of consent is not only a foundational story of twentieth century law. It is also a pillar of contemporary feminism and feminist jurisprudence.

The deference, respect and moral authority we accord the act of consent in these areas of intimate and family life is the subject of this article. Thus, in the bulk of what follows I will put forward a couple of reasons - there may be others -- we might want to rethink the near-absolute moral authority we now accord the operation of what I will sometimes call the "ethic of consent" in these areas of life, and hence the grounds of these vital and still very fragile civil rights. First, I will argue that the authority we accord the act of consent to the creation of our reproductive rights and duties may legitimate the oppression and subordination of caregivers - those who choose to continue pregnancies to term and then to mother their children. That cost should be reckoned and countered, whether or not it is great enough to offset the tangible gains in wellbeing or liberty for those who can now legally choose to terminate or avoid pregnancies. And, that reckoning has simply not happened. Second, the shift from law to consent as a marker of sexual civil rights - reflected in the redefinition of rape law toward a consent-based definition argued for by almost all feminists in rape law scholarship, the focus on affirmative consent as an antidote to sexual assault on college campuses, and the invigorated movement against sexual assault and sexual harassment harbored by the \#MeToo movement -may induce as well as legitimate what I will call a "dysphoric alienation" of the deciding self from the subjective self, and particularly from the subjective hedonic self, for those many women and girls and some boys and men likewise who often or routinely consent to sex when they neither desire, want, welcome, or ultimately find it to be physically pleasurable. That alienation from the hedonic self implies further harms but is also itself a harm, which I suggest we label "hedonic dysphoria." The valorization of an ethic of consent in our various liberal reform movements in the law of rape and sexual assault veils these dysphoric harms, and at the extreme, renders them oxymoronic. Again, we should at least countenance those harms and seek to counter them, and thus far we have yet to do so.

Part Two below elaborates the claim that the ethic of consent now dominates the politics and morality of reproductive and sexual civil rights. Part Three - the major part of the article -begins with an overview of the extensive critical literature on the role of consent in other areas of twentieth century law, and notes the contrast with the relative paucity of critique in the areas of 
sexual and reproductive rights. ${ }^{4}$ It then examines the legitimation costs of the ethic of consent in the realm of reproductive rights, and then looks at those costs in the realm of sexual rights, with a focus on the possibility of hedonic dysphoria as a pervasive and mostly unexplored harm. The conclusion suggests a different grounding for our sexual and reproductive civil rights that appreciates the necessity of consent to the goodness of sexual and reproductive life, but resists the common implication of its sufficiency.

\section{The Ethic of Consent in Reproductive and Sexual Civil Rights}

Up to the last third of the twentieth century, it was not consent, but rather, law, and more specifically, the legally generated status of marriage, that determined both sexual and reproductive rights and obligations. Start with sex: meaning, our sexual roles, rights and responsibilities. Marital rape exemptions directly implied the legality of nonconsensual marital sex, thus underscoring the mandatory nature of female sexual services within marriage. A married woman was obligated by the combined effect of law and status to provide sex; she was not free to choose to do so or not in accordance with her willed power of consent. Outside marriage, meanwhile, sodomy laws, adultery laws, fornication laws and the criminality of prostitution criminalized fully consensual sex whether welcome or not. Thus, both the obligatory sex within marriage regardless of the absence of consent and the forbidden consensual sex outside marriage were regulated, criminalized, or mandated through laws that attached to legally created statuses, rather than according to consent or its absence. It bears emphasis that this was not a nineteenth century, pre-Mainean stage of our ancestors' legal history -- rather, consensual sex outside marriage was criminal and nonconsensual sex within marriage was legal

\footnotetext{
${ }^{4}$ From the realist era, see Robert Hale, Bargaining, Duress, and Economic Liberty, 43 CoLuM. L. ReV. 603 (1943). For examples of critical analyses of the role of consent in contract law that embrace some version of the legitimation critique, from the earlier stages of the critical legal studies movement, see Robert Gordon, Unfreezing Legal Reality: Critical Approaches to Law, 15 Fla. ST. U. L. REv. 195 (1987); Robert Gordon, Law and Ideology, 3 TIKKUN 14 (1988); Duncan Kennedy, Distributive and Paternalist Motives in Contract and Tort Law, With Special Reference to Compulsory Terms and Unequal Bargaining Power, 41 MD. L. REv. 563 (1982); MichAEL J. TREBILCOCK, The Limits of FreEdom of ConTRACT 150 (1993); Alan Schwartz, The Default Rule Paradigm and the Limits of Contract Law, 3 S. CAL. InTER. L.J. 389 (1993); Girardeau A. Spann, A Critical Legal Studies Perspective on Contract Law and Practice, 22 ANN. SuRv. AM. L. 223 (1989) and Allan C. Hutchinson \& Patrick J. Monahan, Law, Politics, and the Critical Legal Scholars: The Unfolding Drama of American Legal Thought, 36 STAN. L. REV. 199, 208-209 (1984). For more particularized criticism of the role of consent in boilerplate contracts see Margaret Radin, Boilerplate: The Fine Print, VANishing Rights AND the Rule of LAW (2012); Margaret Radin \& R. Polk Wagner, The Myth of Private Ordering: Rediscovering Legal Realism in Cyberspace, 73 CHI.KENT L. REV. 1295 (1997-1998); OREN BAR-GILL, SEDUCTION BY CONTRACT: LAW, ECONOMICS AND PSYCHOLOGY IN CONSUMER MARKeTS (2012) and Elizabeth Warren \& Oren Bar-Gill, Making Credit Safer, 157 U. PA. L. ReV. 1 (2008-2009). For critical examination of the role of consent in labor, and how it both contrasts and compares with the role of coercion in slavery see Mark Tushnet, THE AMERICAN LAW OF SLAVERY, 1810-1860: CONSIDERATIONS OF HUMANITY AND INTEREST (1981); Amy Dru Stanley, Conjugal Bonds and Wage Labor: Rights of Contract in the Age of Emancipation, 75 J. AM. HIST. 471 (1988) and Amy Dru Stanley, Book Review (reviewing Tushnet, supra),

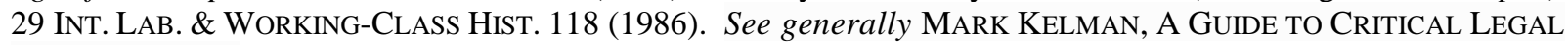
STUDIES (1990).
} 
until well into the 1970s. ${ }^{5}$ Thus, until very recently, it was not consent that determined the line between rape and sex, or between legal and illegal sex, either inside or outside marriage. Rather, it was marriage and marital status that determined the legality of sex, and the responsibility to provide or withhold it.

The same was true, broadly, of reproduction. By virtue of the legality of marital rape, and the illegality of both contraception and abortion, nineteenth and twentieth century American law - again until the 1970s -- went a long way toward ensuring that intercourse within marriage, whether or not consensual, would lead to pregnancies, which would in turn lead to reproduction and maternity. Consent had nothing to do with that progression. Without access to abortion or contraception, repeated penetrative coital sex within marriage will regularly produce a pregnancy followed by a birth, and it will do so with or without a wife's consent to either the sex itself or the pregnancy that results. Reproduction and maternity were thus as mandatory for married women as the sex that led to them; the rights and responsibilities that attached to pregnancy and maternity both in no way hinged on her consent. Outside marriage, the law discouraged extramarital reproduction, and again, the unmarried woman's consent to or desire for the pregnancy had nothing to do with it. The sex that occasioned the pregnancy was a crime, and stigma and financial penalties were visited upon those who bore the status of illegitimacy. Putting these together, marriage, not consent, was the demarcation of the morality or legality of a pregnancy, and the maternity that would follow, no less than of the sex that brought it on: pregnancy within marriage was effectively mandatory no matter how nonconsensual, while pregnancy outside of marriage was stigmatized regardless of how much a pregnancy and a baby were wanted. The marital status, rather than consent, welcomeness, any act of will, or any subjective state of desire dictated the legitimacy of the pregnancies that women either endured or enjoyed. Neither pleasure, desire, willfulness, voluntariness, nor consent had anything to do with it.

This legal regime - the set of laws and practices rendering sex, pregnancies and childbirth mandatory within marriage, regardless of the absence of consent, and forbidden or stigmatized outside marriage, regardless of consent's presence -- gave way, through the last quarter of the twentieth century and the first two decades of this one, to a regime of both maternity and sexuality premised largely upon consent, rather than marital status. Again, start with sex. Rape reform movements that targeted marital rape exemptions, spearheaded by feminists, ${ }^{6}$ effectively reversed the marital regime with respect to mandatory sex within marriage, while various sexual liberation reforms, some of them led by feminists and some not,

\footnotetext{
${ }^{5}$ For a history of the marital rape exemption in $19^{\text {th }}$ century Anglo-American law, see Jill Hasday, Contest and Consent: A Legal History of Marital Rape, 88 CALIF. L. REV. 1373 (2000), and for an intellectual history of the exemption's changing justifications, see Ngaire Naffine, 'Some Gentle Violence': Marital Rape Immunity as Contradiction in Criminal Law, in RESEARCH HANDBOOK ON FEMINIST JURISPRUDENCE 231 (Robin West \& Cynthia Bowman eds., 2019). For an argument that these exemptions violated the $14^{\text {th }}$ amendment's equal protection clause, see Robin West, Equality Theory, Marital Rape, and the Promise of the Fourteenth Amendment, 42 FLA. L. REV. 45 (1990). For a history of the repeal of the exemptions through the 1970s and 1980s, and the forces that facilitated it, including an embrace of some central radical feminist ideals by the legal elite, see Rebecca Ryan, The Sex Right: A Legal History of the Marital Rape Exemption, 20 L. \& So. INQUIRY 941 (1995). On the decriminalization of nonmarital sex, largely through overturning laws establishing a stigmatized status for illegitimate children, see generally NANCY POLIKOFF, BEYOND STRAIGHT AND GAY MARRIAGE: VALUING ALL FAMILIES UNDER THE LAW. (2008).

${ }^{6}$ See Ryan, supra note 5, at 943.
} 
effectively reversed or nullified the criminalization of consensual sex outside it. ${ }^{7}$ What connected these two movements - the movement to criminalize nonconsensual sex within marriage, and the movement to decriminalize consensual sex outside it -- was the centrality of consent to the reform vision of both regimes: the very general idea that consent, rather than marriage, should be the demarcation of legal from illegal sex. There was no Brown v Board of Education, no Supreme Court-led jurisprudential and political and moral shift that presaged or triggered or even celebrated this revolution after-the-fact. But there was, nevertheless, a momentous political and moral shift. Within marriage, a centuries-long regime of mandatory sex imposed upon wives by willful husbands, coupled with the criminalization of consensual sex outside it, gave way to rape laws that criminalize sex not on the basis of marital status, but rather on the basis of consent. Both inside and outside marriage, both the legality and morality of sex now depends largely upon whether or not both parties consented, rather than whether or not the sexual partners were married.

Likewise, with respect to pregnancy and maternity. With abortion largely decriminalized and birth control widely available, and with maternity outside of marriage de-stigmatized, it is no longer a pregnant woman's marital status, but rather the presence or absence of her consent, that dictates when and whether she conceives, the consequences of any pregnancy, and the onset of motherhood, and this is true whether she becomes pregnant within marriage or outside of it. Precisely because of the combined effect of Griswold $v$ Conneticut ${ }^{8}$ and Roe $v$ Wade, ${ }^{9}$ in the US, a woman does not, any longer, simply submit to a complex marital, sexual and reproductive legal regime which imposes a condition - pregnancy - and a status - mother - upon her within marriage, which is then forbidden her outside of marriage. Rather, she wills it into being, whether married or not. Pregnancies are either intentional, or they are avoidable, through birth control, or they can be legally terminated, through abortion. In this sense, pregnancies are now, post-Roe and post-Griswold, broadly consensual. Thus, even after she is pregnant, a woman decides whether or not to remain pregnant and become a mother, and she does so whether or not she is married. She is as free not to be a mother, if she so decides, within marriage, as she is free to become a mother, if physically possible and if she so decides, outside of it. Both depend upon her consent, not her marital status. Neither choice is anywhere near as legally constrained - or determined - as it once was. I'm going to call the legal regime of which this is the consequence "consensual maternity." 10

7 Sociologists and historians differ on the causes and origins of the sexual revolution. See, e.g., Judith Treas, How Cohorts, Education, and Ideology Shaped a New Sexual Revolution on American Attitudes toward Nonmarital Sex, 1972-1998, 45 SOC. PERSP., 267 (2002); Alan Petigny, Illegitimacy, Postwar Psychology, and the Reperiodization of the Sexual Revolution, 38 J. Soc. HIST. 63 (2004); Dagmar Herzog, Syncopated Sex: Transforming European Sexual Cultures, 114 THE AM. HIST. REV. 1287 (2009); William Eskridge, The Many Faces of Sexual Consent, 37 WM. \& MARY L. REV. 47 (1995-1996). For a discussion of the relationship between feminist gains, feminist politics, and feminist scholarship, and the sexual liberation movement, see Nan Hunter, Feminism, Sexuality and the Law, in RESEARCH HANDBOOK ON FEMINIST JURISPRUDENCE 138 (Robin West \& Cynthia Bowman eds., 2019).

${ }^{8}$ Griswold v. Connecticut, 381 U.S. 479 (1995).

${ }^{9}$ Roe v. Wade, 410 U.S. 113 (1973).

${ }^{10}$ Eileen McDonagh is the only major feminist, of whom I'm aware, that reckons with the consensuality or possible non-consensuality of pregnancy, as distinct from the consensuality of the sex that may have brought it into being. McDonagh, however, refers to the current Roe and Griswold regime as a regime of "choice" rather than consent, because so long as an abortion is not freely available to a woman undergoing a pregnancy, that pregnancy cannot be characterized as consensual. I agree that the costs of abortion often render a pregnancy coerced, but I do not believe 
If we put this together with the parallel revolution in the way we now think of sexual life - sex is legal not so long as it is marital, but rather so long as it is consensual - we can reach some broadly syllogistic conclusions. For a married woman at mid-twentieth-century, sex, conception, pregnancy, childbirth and motherhood were all not just permitted but mandatory. Her lack of consent was irrelevant to her nonwaivable duty to engage in sex, to conceive, to carry the pregnancy to term, to give birth and then to mother. For a woman outside marriage, the mirrored opposite was true: sex, conception, pregnancy and motherhood were all either criminalized or disincentivized, and all regardless of her consent. Marriage, status, and law were the determinants of reproductive and sexual life and behavior both, not consent or its lack. Today, that's all been flipped: neither reproductive nor sexual duties, rights, and responsibilities turn on status, and indeed to argue that they should is widely regarded as advocating the imposition upon women of a regime akin to slavery. ${ }^{11}$ Taken collectively this constitutes a striking and pervasive movement from law to consent. The magnetism of consent has pulled within its orbit virtually all of the familial, sexual and reproductive rights attached to gender which were once unambiguously a function of law and status, and which are now also unambiguously regarded as hard fought and newly won civil rights.

The civil rights for women that have come on the heels of this revolution - and particularly the civil rights to be free of assaultive sex and mandatory maternity, but also the civil rights to engage in consensual sex and maternity outside of marriage -- have not been a consequence of a wider or more expansive reading of antidiscrimination law, nor have they been won through adherence to any conception of formal equality. Neither Title VII law nor the antidiscrimination norm of the fourteenth amendment, nor the ideal of formal equality that in some form animates both, were the primary legal tool with which these gains in women's civil rights were secured. Doctrinally, the revolution in women's civil rights around reproductive autonomy came from judicial interpretation of the constitutional norms around privacy and liberty - and (somewhat notoriously) not from anything relating to nondiscrimination or equal protection. ${ }^{12}$ The revolution in rights around sexual autonomy came primarily from state legislative changes to rape laws, ${ }^{13}$ by Congressional passage of the Violence Against Women

that those forces are so extreme as to render the pregnancy nonconsensual. Choices are often regarded as consensual, even when they are constrained by ability to pay, and the ability to carry a pregnancy to term may be broadly consensual in that way. I don't believe anything turns on this word choice, however, and I am otherwise in accord with her analysis. See EILEEn MCDOnAGH, BreAKING THE AbORTION DeAdlock: From CHOICE TO CONSENT (1996); West, Liberalism and Abortion 87 GEO. L.J. 2117 (1999).

${ }^{11}$ See Andrew Koppelman, Originalism, Abortion and the Thirteenth Amendment, 112 COLUMBIA L. REV. 1917 (2012) and Jed Rubenfeld, The Right of Privacy, 102 HARVARD L. REV. 737 (1989). See also Robin West, Hobby Lobby, Birth Control, and Our Ongoing Culture Wars: Pleasure and desire in the Crossfires, 26 HEALTH MATRIX 67 (2016).

\footnotetext{
${ }^{12}$ Feminists have criticized Roe from its inception for relying on privacy rather than any notion of equality as the foundation for abortion rights. See Ruth Bader Ginsburg, Some Thoughts on Autonomy and Equality in Relation to Roe v. Wade, 63 N.C. L. REV. 375 (1985); Catharine MacKinnon, Reflections on Sex Equality Under Law, 100 YALE L.J. 1281 (1991).

${ }^{13}$ See Hasday, supra note 5; Ryan, supra note 5; West, Equality Theory, supra note 5, on changes to marital rape laws. See Stephen Schuelhofer, Unwanted SeX: The Culture of Intimidation And THE FAILURE OF LAW (1998) on changes in rape laws, toward consent rather than force. See MacKinnon, Rape Redefined, 10 HARV LAW AND POLICY REVIEW 431 (2016) on redefining rape law and criticizing the move to consent-based definitions.
} 
Act, ${ }^{14}$ and repeal or relaxation of laws criminalizing fornication, adultery, sodomy and prostitution. In all of these cases, the legal changes followed political and legal movements that stressed neither antidiscrimination, nor formal equality, but rather, a woman's rights to the exercise of choice, to the availability of exit, to her capacity to consent, and to physical and moral autonomy. They rested on the overall case for giving to women the choice to become a mother or terminate a pregnancy, of endowing her with the right of sovereignty over her own body and her enjoyment of physical integrity, of recognizing her need for agency in her own life, including sexual agency, of acknowledging a woman's right and capacity to say yes to sex or maternity outside of marriage as well as her right to say no within it. Women's reproductive and sexual civil rights were borne, in short, of the need to be rid of a status-driven and law-defined existence and to enjoy instead a self-willed one, with respect to sexuality, reproduction, pregnancy, and motherhood all. They create, confer, and validate women's powers to consent to consent, or to withhold consent, from sex, and to consent, or to withhold consent, to pregnancy and motherhood - rather than have the rights and responsibilities of sexual and maternal labor assigned by status and law. They are in accord with the deepest impulses of the Maine-ean narrative: the movement from status to contract as the font of rights and responsibilities, and underlying that shift, the movement away from law and toward consent, as the means by which those rights and responsibilities come into being. And, as such, they bring the promises of liberalism and liberal legalism at least within reach of women's reproductive and sexual lives: precisely the group of people and the areas of life initially excepted from Maine's historic account of the arc of nineteenth century law toward consent and contract.

\section{Legitimation Costs}

Let me turn now to some of the costs of this turn toward consent, and away from the law, as the font of rights and responsibilities in women's sexual and reproductive lives. According to a sizeable body of critical legal scholarship developed in the 1970s, 80s, and 90s, our reliance on consent, rather than law, as the marker of what is legal and what is not, particularly in marketbased liberal political structures, has the side effect of legitimating that to which consent has been given as good, as well as legal, and thereby cordoning off from criticism as well as political change three things: the value of the transaction itself, the fairness of the social world that motivated it, and the overall goodness or utility of the post-consent world it brings into being. ${ }^{15}$ A sizeable body of critical scholarship has identified all three sorts of legitimating consequences in consumer transactions and labor contracts. ${ }^{16}$ Thus, in consumer transactions, the consent of the

\footnotetext{
${ }^{14}$ Violence Against Women Act, Pub. L. No. 103-322, tit. IV, 108 Stat. 1902 (1994).

${ }^{15}$ The idea of legitimation as a worrisome tendency in liberal and capitalist systems of law was introduced into the critical literature by Antonio Gramsci. It became a central tenet of critical legal studies in the 1970s and 1980s. See Edward Greer, Anontonio Gramsci and Legal Hegemony in THE Politics of LAW: A ProgRessive CRITIQUe (David Kairys ed., 1998); RobIN West, NORMATIVE JURISPRUDENCE: AN INTRODUCTION, at 143-51 (2011). The idea became central to Critical Race Theory as well, although with significant reservations: the suggestion that legitimation is the vehicle for oppression in liberal societies seems to mute the dangers posed by actual racial violence. For general discussion of the role of legitimation in CLS and CRT, see Mari Matsuda, Looking to the Bottom: Critical Legal Studies and Reparations, 22 HARV. C.R.-C.L. L. REV. 323 (1987); Richard Delgado, The Ethereal Scholar: Does Critical Legal Studies Have What Minorities Want, 22 HARV. C.R.-C.L. L. REV. 301 (1987); Kimberle Crenshaw, Race, Reform, and Retrenchment: Transformation and Legitimation in Antidiscrimination Law, 101 HARV. L. REV. 1331 (1988).

${ }^{16}$ See, e.g., Robert Gordon, Unfreezing Legal Reality, supra note 4; Robert Gordon, New Developments in Legal Theory, in THe Politics of LAW: A Progressive CRITIQUe (David Kairys ed., 1982); Jay Fineman, Critical Approaches to Contract Law, 30 UCLA L. REV. 829 (1982-1983); Elizabeth Mensch, The History of Mainstream
} 
buyer and seller to a trade shields the fairness of the world that motivated the trade, as well as the decency or goodness of the world it brings into being, from any sort of meaningful critique.

Likewise, according to the legitimation critics, the consent of a laborer to a labor contract shields the fairness of the background conditions of the labor relation and the goodness of the new world it creates, from moral criticism, and therefore from political change. ${ }^{17}$ And third, the participants to these labor and commercial transactions regularly over-value that for which they have traded: in short, consent confers excess "goodness," or value, on that to which consent is proferred.

This is, generally, what I take the "legitimation critique" from 1970s, 1980s and 90s critical legal scholarship to have claimed: the consent to a labor or commercial transaction legitimates the background conditions that motivated the consent, the goodness of the world the consensual transaction brings into being, and the value of that for which a consent is tendered. ${ }^{18}$ There is, now, a sizeable legal scholarship focused on the legitimation costs, thus understood, of a range of consensual transactions in labor and commercial markets. Yet: there is no similar critical scholarship regarding women's reproductive and sexual rights - precisely the area of civil rights law in which consent looms so large as to cast in shadow other egalitarian civil rights values. This is, if nothing else, anomalous. The divide between legal sex and rape now turns on the presence or absence of consent, no less than does the divide between theft and exchange, and between labor and slavery. The rights to reproductive liberty that emanate from Roe and Griswold are also grounded solidly, both in law and in the public mind, in the ethic of consent. If anything, the legitimating rhetoric of consent is greater in the reproductive and sexual context than in the contexts of trade and labor. Given our embrace of LGBTQ rights, our overdue

Legal Thought, in THE POLITICS OF LAW, supra; Peter Gabel and Jay Fineman, Contract Law as Ideology, in THE POLITICS OF LAW supra; Robin West, Authority, Autonomy and Choice: The Role of Consent in the Political and Moral Theory of Richard Posner and Franz Kafka, 99 HARV. L. REV. 384 (1985); Mark Kelman, Choice and Utility, 1979 WIS. L. REV. 769 (1979).

17 Robert Hale introduced these skeptical ideas regarding the reliability of consent in labor contracts into the legal realist literature in Coercion and Distribution in a Supposedly Non-Coercive State, 38 POLITICAL SCIENCE QUARTERLY 470 (1923). See generally BARBARA FRIED, THE PROGRESSIVE ASSAULT On LAISSEZ FAIRE: ROBERT HALE AND THE FIRST LAW AND ECONOMICS MOVEMENT (2001).

18 The reasons people may be wrong about their own self-interest are well discussed in Mark Kelman's seminal CLS essay, Choice and Utility, supra note 16. Since Choice and Utility appeared, an entire subfield of behavioral economics and psychology has emerged, tracking the various cognitive biases that might impact individuals' assessments of their own self-interest. For a good introduction and discussion, see Cass R. Sunstein, Christine Jolls \& Richard H. Thaler, A Behavioral Approach to Law and Economics, 50 STAN. L. REV. 1471 (1998). For a critical discussion of the cognitive bias school, and its relationship to other movements in behavioral psychology, with a focus on relevance for law, see MARK KELMAN, THE HEURISTICS DEBATE (2010), and for a review of Kelman's contribution to that debate, see Robin West, Adjudging the Heuristics Debate, JoTwELL (February 2013)

(Reviewing Kelman, The Heuristics Debate (2010)), See also Duncan Kennedy, supra note 4. For an account more friendly to economics, of how consumers can overvalue consumer goods, see Russell Korobkin, $A$

'Traditional' and 'Behavioral' Law-and-Economics Analysis of Williams V. Walker-Thomas Furniture Company, 26 HAWAII L. REV. 441 (2004).

It may be that elites believe this more than others, particularly legal elites. Both Kelman and Kennedy stressed the degree to which an abstract and formal conception of "efficiency" dictated allegiance to what I am calling the Ethic of Consent. Kelman, Choice and Utility, supra note 16, at 771-72; Kennedy, supra note 4, at 587, 621. I discuss these and other possible accounts of the divide between actual self-interest and preference in Robin West, The Other Utilitarians, in ANALYZING LAW: NeW EsSAYs In LEGAL THEORY (Brian Bix ed., 1998). 
rejection of the stigma of illegitimacy, the sexual revolution writ large, and general endorsement of the broad contours of liberal sex education in public schools, we now laud consensual sex more assertively and with greater confidence than we laud consensual labor, and given Roe and Griswold, we now laud consensual pregnancies, and lament nonconsensual ones, in the ways we once lauded marital pregnancies and lamented pregnancies outside marriage. The ethic of consent has now so thoroughly supplanted the regime of law in the creation of the rights and responsibilities surrounding sex and pregnancy, I would predict, as to withstand backlash on sexual rights and even the reversal of Roe $v$ Wade: the sex and the pregnancies we value and valorize will continue to be those triggered by individual acts of will, rather than those imposed by the constraints and restraints of the law of marriage. If this is right, then consensual sex and pregnancy, as well as consensual maternity, one might conclude, might likewise carry legitimation costs. Yet, there is only a very limited body of literature exploring what those costs might be. This is, simply, odd: those costs may be substantial. So, in what follows, I'll try to elucidate some of them.

\section{A. The legitimating harms of consensual reproductive rights}

I'll begin with the harms that might be legitimated by the ethic of consent, as it pertains to pregnancy, in the post-Roe and post-Griswold era, and then I'll turn to the harms legitimated by the ethic of consent as it pertains to sex. On pregnancy, there are at least three. First, and as Catharine MacKinnon argued forty years ago, overvaluing a pregnancy because of the consensuality conferred upon it by Roe and Griswold might legitimate the sex that produced the pregnancy, yet this might include a lot of nonconsensual, forced sex. ${ }^{19}$ This is an example, using the structure of legitimation critiques I outlined above, of a consensual transaction legitimating the background conditions that motivated it, or what I'll called the "upstream conditions." If pregnancies are regarded as constructively "consensual" because of the power to avoid them or terminate them, then nonconsensual, forced sex, at least in popular as well as legal understanding, no longer carries the risk of nonconsensual pregnancy. And, it is of course true that a rape does not, today, carry the risk of a nonconsensual pregnancy carried to term, where the pregnancy can be legally terminated. The availability of legal abortion has thus reduced the harmful consequences of rape, thereby to some measure legitimating it, or at best, rendering its remaining harms that much harder to see. Of course, abortions are costly, morally problematic for many, traumatic for some, and physically difficult experiences for anyone. Nevertheless, the bald fact that an unwanted pregnancy can be terminated carries the unwarranted implication that all pregnancies, including those that result from rape, are consensual, and hence harmless. The consensuality of pregnancy implied by the availability of abortion thus reduces the perception of the harmfulness of rape, which is difficult to see in any event.

More broadly - and this is the larger concern that prompted Catherine MacKinnon's critique not just of Roe $v$ Wade but of the pro-choice movement generally - the apparent consensuality of pregnancy implied by the legality of abortion, can wrongly legitimate not just the harms of rape, but also the harms of coerced sex that can result in pregnancies, where the coercion falls shy of the degree of force necessary to vitiate consent. ${ }^{20}$ And much of the sex in

\footnotetext{
${ }^{19}$ CAtharine A. MacKinnon, Privacy v. Equality: Beyond Roe v. Wade, in FeminiSM UnMODIFIED: DisCOURSES ON LIFE AND LAW 93 (1987).

${ }^{20} I d$., at 99 ("The availability of abortion removes the one remaining legitimized reason that women have had for refusing sex besides the headache.")
} 
which women engage is the result of coercive pressure. The wrongness of consensual but coerced sex, particularly outside marriage, was long attributed largely to the burdens of the nonconsensual pregnancy that might follow. With abortion legal, and pregnancies that are not terminated thus presumptively consensual, coercive sex no longer carries a risk of nonconsensual pregnancies: as is true of pregnancies caused by rape, the wrongness of consensual but coerced sex is mitigated by the availability of legal abortion, should an unwanted pregnancy ensue. Unlike rape, however, the wrongness of consensual but broadly coercive sex is not only hard for many to see, it is flatly denied across any number of cultural lines, and for a host of reasons, which I'll explore below. The consensuality of the pregnancies that follow coercive sex, however, given the availability of abortion, is one such reason.

Putting these points together, Roe, Griswold, and the regime of consensual reproduction they ushered in, diminish the wrongness of the assaultive or coercive sex that often precedes and causes it. If nonconsensual pregnancy carried to term is no longer a mandatory consequence of coerced sex, then there is that much less reason for a woman or girl to resist coercive sex, that much less reason for a man to refrain from imposing it, and that much less reason likewise to societally discourage its occurrence. Coerced, unwanted, un-pleasurable, undesired, and unwelcome - albeit consensual - sex becomes at worst simply a bad transactional experience, rather than a calamitous life-changing event: it occasions bad sex and the discomfort and expense of an abortion but with no long-lasting harms. The harms of the sex, as well as the harms that may be directly consequent to the abortion itself, are further obscured.

Again, the above critique - which I'm recharacterizing as a legitimation critique -- was first put forward in Catharine MacKinnon's early writing on Roe, Griswold, the pro-choice movement and liberal feminism across the board. ${ }^{21}$ There is, however, at least one additional legitimation costs of the ethic of consent in the context of reproduction which she did not recognize at all, and which has gone largely unnoticed in our post Roe and Griswold era. The consensuality of the pregnancies that precede maternity, given the reproductive rights created by Roe and Griswold, legitimates the paucity of rights that attach to the caregiving that follows the birth, for those consensual pregnancies that are carried to term. Heterosexually active women have civil and even constitutionally protected rights to contraception with which they can avoid maternity, and pregnant women (still) have rights to abortion services to do likewise. Caregiving women, however, who bring a pregnancy to term, whether they wanted the pregnancy or not, have virtually no rights that attach by virtue of the caregiving, and from the moment of pregnancy forward. A pregnant woman has a constitutional right to terminate the pregnancy, but she has no rights to assistance with the financial, medical, physical and emotional costs of the pregnancy, should she decide to carry the pregnancy to term, from either her sexual partner, the community, or the state. There is no such thing as "preglimony," as Sheri Motro now calls it. ${ }^{22}$ Nor does she have rights to assistance with the costs of the childbirth. This "rightlessness" regarding the pregnancy itself bleeds over into a lack of rights postpartum, particularly vis a vis the state. A new mother has no constitutional or civil right to assistance when she is fully incapacitated from employment by virtue of the aftermath of childbirth and lactation, and she likewise has no constitutional or civil right to longer term assistance when her caregiving labor

\footnotetext{
${ }^{21}$ MacKinnon later revisited legal abortion, arguing that its justification should be grounded in equality principles. MacKinnon, Reflections on Sex Equality Under Law, supra note 12.

${ }^{22}$ Shari Motro, Preglimony, 63 STAN. L. REV. 647 (2011); Shari Motro, Responsibility Begins at Conception, N.Y. TiMES (July 6, 2012), https://nyti.ms/2zBSQbi.
} 
compromises her capacity to engage in market based labor for compensation during the years of maternity following a birth. No constitutional or civil right to assistance follow from a recognition of the value of the caregiving itself, combined with a recognition of the vulnerability to which that caregiving leads. The consensuality of the pregnancy reinforces and gives additional credence to this pre-existing regime.

This is part of a larger phenomenon that I have addressed in some detail elsewhere: caregivers in the US - and of both sexes and all genders, and whether the object of the caregiving is a newborn, a child, an elder, or a disabled dependent -- are bereft of rights. ${ }^{23}$ Some caregivers enjoy a highly circumscribed and uncompensated legal right, under the Family and Medical Leave Act, ${ }^{24}$ to not lose a job for three months following a birth, adoption, or family sickness, if the caregiver has the right kind of job and a host of additional requirements are met. ${ }^{25}$ Those rights, however, are grounded not in a recognition of the value of caregiving, but in a worry that a woman's caregiving will lead to stereotypical beliefs that will in turn trigger discrimination in the workplace. ${ }^{26}$ Likewise, some caregivers have limited statutory rights to some state assistance toward the costs of food and shelter for their dependents, but those rights again are heavily circumscribed, and grounded not in a recognition of the value of caregiving, but in a recognition of the needs of dependent infants. ${ }^{27}$ And, it is worth stressing: there is no recognized civil or constitutional right to any of that assistance. FMLA could be reversed tomorrow with no infringement of anyone's constitutional or civil rights. ${ }^{28}$ Aid to mothers or parents or families with infant children is a set of fragile entitlements parceled out according to changing political whims, which could drop to zero with no infringement of anyone's rights. Caregivers qua caregivers simply do not enjoy any kind of a right to community support that is both resilient against political change and which stems from the recognized value of the caregiving labor itself. When maternal caregiving was mandatorily tied to marriage - when pregnancies were valorized within marriage, regardless of consent, rather than the other way around - there was a brutal logic to this paucity of rights: the support for the caregiver presumptively came from the husband, who had both the power to mandate it and a duty to support it. Those presumptions wither away under a legal regime structured by the ethic of consent rather than the ethic of marriage. That fact was not lost on the armies of women who opposed the ERA in the 1970s. ${ }^{29}$

\footnotetext{
${ }^{23}$ Robin WeSt, CARING FOR JUSTICE (1996); Robin West, The Right to Care, in FEDER AND KITTAY, ED's, The SubJeCt OF CARE: FEMINIST PERSPECTIVES ON DEPENDENCY (2003) 88.

${ }^{24}$ Family and Medical Leave Act of 1993, 29 U.S.C. $§ 2601-2654$ (2012).

${ }^{25} \mathrm{Id}$. $\S 2611$ (2), on eligibility of employees and exclusions.

${ }^{26}$ See Nevada Dep't of Human Res. v. Hibbs, 538 U.S. 721, 736 (2003).

${ }^{27}$ Personal Responsibility and Work Opportunity Reconciliation Act of 1966, Pub. L. No. 104-193, § 729 (1996)

${ }^{28}$ Justifications for state assistance to poor families have ranged from recognition of the needs of the deserving poor, to the need to protect the wellbeing of children who are innocent of their parents' sins, to the laudatory goal of sending parents back to work, the less laudatory and likely racist goal of limiting the number of children low income women can have and still be entitled to support, and incentivizing would-be mothers to marry. Aid to Families with Dependent Children, Title IV of the Social Security Act of 1935, replaced by TANF 1996; Personal Responsibility and Work Opportunity Reconciliation Act of 1966, Pub. L. No. 104-193, § 729 (1996). For critique, see EvA KitTAy, LOVE's LABOR: ESSAYS ON WOMEN, EQUALITY AND DEPENDENCY (1998). See also Robin L. West, Do We Have a Right to Care?, in THE SUBJECT OF CARE: FeMINIST PERSPECTIVES ON DEPENDENCY 88-114 (Ellen K. Feder \& Eva Feder Kittay eds., 2003).

${ }^{29}$ JANE J. MANSBRIDGE, Why We LOST THE ERA 90-117 (1986); KRISTIN LUKER, ABORTION AND THE POLITICS OF MOTHERHOOD 158-191 (1984)
} 
With maternal caregiving - the consequence of consensual pregnancy -a freely willed result of a consensual transaction, rather than an unwilled consequence of marital status, and widely viewed as such, the woman who engages in it is participating in a form of individualized self-actualization previously denied her. She is also, however, doing so from a posture and in circumstances where thriving, and even surviving, without considerable support from somewhere - a spouse, a partner, a community, an extended family, or the state -- is flatly impossible. One cannot support oneself, or fulfill one's own needs, much less the needs of one's dependents, while giving birth, breastfeeding, or tending the needs of infants, babies, toddlers and preschoolers, without assistance, and a lot of it. The demands of caregiving to human infants are inconsistent with the conception of humanity that undergirds liberal assumptions of individualized independence, and the rights that attach to that understanding. ${ }^{30}$ Without rights, the woman or the man engaged in caregiving work is thus in a position of requiring assistance according to the will of unencumbered co-citizens, rather than of possessing an entitlement to assistance by right. The movement from marital status to consent as the framework within which reproductive life is structured did not cause, and may not even have exacerbated this rightlessness, but it has, I believe, legitimated it, at least in the United States. It is just that rightlessness, and the harms consequent to it, that is most legitimated by our valorization of consensual ethics in reproductive life.

The incompatibility of caregiving with the understanding of individualism at the heart of liberalism - and at the heart of consensual ethics -- is familiar to some forms of feminism, and indeed to an array of liberalism's non-feminist critics as well, including some communitarians, ${ }^{31}$ some Marxists, ${ }^{32}$ and some social conservatives. ${ }^{33}$ The incompatibility of caregiving with the most prominent liberal theories of the state also predates both liberal individualism and the rise of the ethic of consent: pioneering and revolutionary women worldwide have struggled against the infantilization and exclusion from political and economic life that is inherent in unassisted caregiving. This is too long a history to even nod toward summarizing. My point here is only that what the ethic of consent adds to this historical conundrum is twofold. First, by giving women an exit through reliable birth control and legalized abortion, it provides the liberating possibility of refusing the caregiving role. Perhaps caregiving is incompatible with liberalism, but at least I don't have to partake of it; if I enjoy liberalism and the joys of individualism it bestows I can say no to maternity. There is no denying the significance of that liberation. What it also adds, however, is a massive dollop of legitimation to the incompatibility itself, as well as to the struggles of women who do -- voluntarily or otherwise -- take up maternity. The struggles, difficulties, and, for those living on the margins, the sheer impossibility of giving care to infants and other severely incapacitated dependents in the face of the familiar demands of liberal and individualist self-determination are mightily and even viciously legitimated by the gloss of voluntarism, and with not altogether different consequences from their earlier encasement in a sphere of domesticity. To put it pithily, as it was put to me decades ago by a

\footnotetext{
${ }^{30}$ Martha Fineman, THE Autonomy Myth: A THeory of DePendency (2005); MARTHA Fineman, The VULNERABLE SUBJECT: ANCHORING EQUALITY IN THE HUMAN CONDITION (2013).

${ }^{31}$ See , e.g., Peter Gabel, The Desire For ReCognition: Social Movements AND the DisSOlution of the FALSE SELF (2018).

${ }^{32}$ For a general discussion of the fraught relationship between Marxism and feminism on the issue of caregiving, see Cynthia Bowman, A Plea for a Socialist Feminism, in RESEARCH HANDBOOK ON FEMINIST JURISPRUdENCE 91-111 (Cynthia Grant Bowman \& Robin West eds., 2019).

${ }^{33}$ MARY ANN GLENDON, Rights TALK: THE IMPOVERISHMENT OF POLITICAL DisCOURSE (1991).
} 
law partner at Morrison Forester, who objected to pressure on his firm by feminists and fellow travelers to adopt some form of paid maternity leave for staff and junior associates: the decision to parent is now just as consensual as the decision to sail around the world, and it should be regarded as such. Both are hugely expensive and consequential decisions that in some measure incapacitate one from market-rewarded labor. But in both cases, those consequences are consensually assumed by the individual making the choice. The community has and should have no role in reassessing the entailed costs and benefits. In both cases, consent entails a willed acceptance of those costs and risks by a presumptive adult, and in both cases, there is no objective footing for a realignment.

Grounding reproductive rights in an ethic of consent thus legitimates not only the particularized harms borne by the particular women who so consent, but likewise legitimates a regime - a regime dominated by liberal and neo-liberal ideals, in which the costs of caregiving are entirely or near-entirely privatized, caregiving itself is relegated to the marginal and inessential, and the decision to engage in it rendered no more consequential than any other consumer choice or life style, one possible path that may or may not be chosen. It is a choice, and as such, it is not understood as a necessary or essential life activity worthy of support, it is not constructed or protected by rights, and it is only minimally and contingently supported by ordinary law. It is not a defining characteristic of a part of our humanity that must or should be included in a broad civil vision of inclusion. It is central to neither humanity nor identity. Caregiving itself, therefore -- as contrasted with an individual's decision to avoid it -- cannot and should not ground civil rights, no matter how conceived. Rather, it is a choice among others, and while our civil rights might and happily do protect its voluntarism, that is the end of it: once the choice is made, the ethic of consent takes over. That which is chosen is virtually by definition not that to which civil rights attach and Roe and Griswold, taken jointly, confer the choice. As is true of all choices, post Roe, the choice to mother entails an acceptance of the risks and benefits that flow. Like all such choices, it both facilitates and justifies the withdrawal of communal support - again, particularly in the United States -- for the burdens that choice imposes.

Consensual reproduction elevates reproductive life from a domain of enforced domestic servitude, to a world of individualized consent. The liberatory consequences of that change are clear and clearly historic. The legitimating consequences are not so clear, but they are severe: the move from law to consent in reproductive life legitimates a regime in which impoverishment is not just a predictable but also a fully acceptable consequence of the individual's choice to expend part of her commodifiable life - her human capital - immersed in the work of giving care to dependents. This is immoral, and tragically so. The centrality and nature of reproduction requires a liberal rethinking, and reconceptualization, of the human experience, and not just a rethinking of our commitment to women's equality. Organized feminism, including academic feminism, should be forcing that rethinking. Reproduction, including reproductive choices, cannot be subsumed within a conception of rugged and self-sufficient individualism. We used to understand that: individualism as it was once conceived steadfastly depended upon a subordinate other to do the work reproduction entails. The ethic of consent in the context of reproduction in effect pulled reproduction out of the domain of female subservience and into the domain of individualism. This was liberating, but it also required the near impossible: nurturing the life of a completely dependent human being, without support. It legitimated the resulting misery within a gauze of consent to that impossibility.

\section{B. The Legitimation Costs of The Ethic of Consent in Sexual Life}


On leaving this sphere (of liberal ideology)... which furnishes the "Free-trader Vulgaris" with his views and ideas, and with the standard by which he judges a society based on capital and wages, we think we can perceive a change in the physiognomy of our dramatis personae. He who was previously the money owner now strides in front as capitalist; the possessor of labour-power follows as his labourer. The one with an air of importance, smirking, intent on business; the other timid, and holding back, like one who is bringing his own hide to market and has nothing to expect—but a hiding. ${ }^{34}$

The evolution away from law and toward the ethic of consent as the foundation of sexual rights and responsibilities, can be seen in any number of areas of law, but most clearly in contemporary legal reform movements regarding rape and sexual assault. What was once the "reform" liberal-feminist position on the law of rape - that consent should be the demarcation of legal from illegal sex (rather than some combination of non-marital status, force, and resistance) - is now widely accepted as largely correct, certainly in popular culture and popular understanding, and more slowly, but seemingly inevitably, in law. Requirements of utmost resistance, force, and of a nonmarital connection between a rapist and his victim are being eroded, where they still exist at all, leaving a clean definition of rape or sexual assault (with gradations) as sexual contact without consent. This is a momentous development, widely lauded as a significant gain in women's civil rights. To whatever degree it holds, women and girls have considerably more freedom, and equality, than they had under traditional and far more restrictive understandings of the nature of rape and its harms.

More problematically, however, consent is also increasingly understood as the moral, and not just the legal, demarcation of acceptable or laudable sex on the one hand, from morally unacceptable sex on the other. The shift to consent as both the demarcation of morally unobjectionable sex, and the demarcation of what is legal and what is not, is reflected broadly in a number of cultural and social trends. It is what we - meaning parents and sex educators teach our teenage children they should embrace as a central tenet of sexual ethics as well as dictating what they must do, legally, before initiating or engaging in a sexual encounter. It is the message of soft core pornography and popular entertainment likewise: where all parties consent, sex is good and to be celebrated, whatever its content. The erotic downside of this valorization of consent is that sexual partners must be careful to ensure that each partner has indeed consented to each other's sexual overtures. That has costs to pleasure; it can be a buzzkill. The upside, though, is huge: so long as it is consensual, sex, whether it is premarital, extramarital, part of a long term relationship or casual, and whether it is vanilla or sado-masochistic, and whether it involves multiple parties or traditional pairings, and of course regardless of the sexual orientation or gender of the parties, is all basically immune from criticism, and our teachings on the morality of sex squarely reflect that conviction. It is the ethic that is reflected in our acceptance of minority sexual and gender orientations, including the celebratory weddings, parties, anniversaries and rituals that once attended only privileged sexual and gender orientations. With all colors of the rainbow now unambiguously included in the kingdom of sexual acceptability, it is now uniformly consent, rather than either the sex or gender of the partner, or the marital status of either, or the number of partners, or the vanilla-or-otherwise nature of the sex, that determines a sexual encounter's value.

\footnotetext{
${ }^{34}$ KARL MARX, DAS KAPITAL at 123 (1867). (https://www.marxists.org/archive/marx/works/download/pdf/CapitalVolume-I.pdf)
} 
And finally, and central to my purposes here, sex is now widely insulated from criticism, so long as it is consensual, regardless of the motive that triggered the consent, including motives that trigger exchanges of sex for goods, commodities, money or services that have nothing whatsoever to do with sexual pleasure -- Helen Gurley Brown, of Cosmopolitan Magazine, for example, famously opined five decades ago that sex in exchange for a tip about where one might find a really excellent electric blanket struck her as a good deal. ${ }^{35}$ So, not only sex for pleasure but also sex in exchange for tips on electric blankets, sex for survival, sex for exercise, sex for money, sex for diversion, sex for release from stress, sex as entertainment, sex as an expression of friendship, or sex as expressive of any other impulse is all equally insulated from critique so long as it is consensual. That motive doesn't matter, in fact, is a part of the essence of the ethic of consent; it is at that ethic's heart, not periphery. Consent might be given to sex for any reason or no reason. So long as it is given, though, it is no more to be criticized or condemned as sex, marital or otherwise, that aims for conception or that embodies, constitutes, or reflects long lasting emotional commitment.

As in reproductive life, the liberatory implications and benefits of our embrace of the ethic of consent in sexual life are striking, and by now pretty well understood. Basically, women are less subject to the risks of rape, when sexual assault is defined as nonconsensual sex rather than defined more restrictively, and all of us, but particularly sexual minorities, are less subject to the risks of legal persecution or cultural condemnation, for any and all of our mutually consensual sexual acts, proclivities, tastes, orientations, or identities. But as in the realm of consensual reproduction, there are less obvious costs of the turn to the ethic of consent that are to date unreckoned. Some consensual sex, insulated from criticism as well as legal regulation, comes with significant risks of harm that are legitimated by the consensuality of the sex that causes them. Indeed some of those harms are not just legitimated, but they are rendered nearly incomprehensible - basically viewed as oxymoronic - by large swaths of contemporary liberal polity and culture both.

This is changing. As recently as ten years ago even the possibility of consensual but nevertheless harmful sex was seemingly unthinkable, at least to many liberals, sex positive radicals, and cultural libertarians. It is quite a bit less unthinkable today - in part because of the spill-over impact of the \#MeToo movement, ${ }^{36}$ in part because of the heightened visibility of women's civil right to workplaces and schools free of sexual harassment that movement has occasioned, and in part because of the renewed attention to the early work of Catharine MacKinnon, which that movement has in turn sparked. Problematic but consensual sex, and the legitimating impact of the consent which precedes it, is now discussed in sub-streams of feminist and legal feminist literature (although often not in these terms) far more frequently than in

\footnotetext{
${ }^{35}$ See Caitlin Flanagan, The Woman who encouraged Women to be Girly on the Path to Equality, WASH. POST (Apr. 8, 2016) (reviewing Brooke Hauser, ENTER Helen GuRley Brown AND THE RiSE OF THE SingLE WOMAN). ${ }^{36}$ See Robin West, Manufacturing Consent, THE BAFFLER NO. 39 (2018), https://thebaffler.com/salvos/manufacturing-consent-west. For a critique of the way that sexual harassment blurs in the MeToo Movement with unwanted sex, see Caitlin Flanagan, The Conversation \#MeToo Needs to Have, THE ATLANTIC, Jan. 29, 2018, https://www.theatlantic.com/politics/archive/2018/01/the-right-conversation-formetoo/551732/
} 
decades past. ${ }^{37}$ It has also become the subject of a fair amount of social science research. ${ }^{38}$

In this section I want to first recharacterize some of the harms of consensual sex that have been obliquely recognized for decades, but now much more explicitly discussed in the literature prompted by the \#MeToo movement. I then want to discuss in more detail the particular harm I've referenced in the title of this chapter: what I'm calling hedonic dysphoria, which has not, to date, been explicitly referenced, much less explored or debated. My aim is just to sketch its contours, and to suggest that this is a pervasive type of harm that is not just legitimated by, but in some ways literally caused by our embrace of the ethic of consent in sexual life. It strikes me as the harm occasioned by our embrace of the ethic of consent in sexual life that is both least understood, least visible, and most in need of greater critique.

But first on the somewhat more familiar harms. Here, as in the context of reproduction, some of the costs of our turn to consent, and away from law, as that which demarcates the legal from the illegal in sexual life can be broadly understood as "legitimation costs": they are costs of the aura of legitimacy which consent confers on the background conditions, the downstream consequences, and the underlying transaction occasioned by the act of consent. The ethic of consent thus valorizes and legitimates - as well as legalizes - all consensual sex, again, so long as there are no third-party effects. My basic claim is simply that all of that legitimated and valorized consensual sex might include a lot of sex that is positively harmful, and ought to be regarded as morally problematic, even where it ought not be legally regulated. Given the ethic of consent, it's hard to even suggest this as a possibility. In effect, consent hides the harms of the sex it legitimates behind a veil of consensuality and legality, just as consensuality hides the harms of consensual pregnancy and maternity. But the harms are different.

What kinds of potentially harmful sex might be wrongly legitimated by the ethic of consent, and what are the harms consequent to that sex that might be veiled because of it? A listing might be in order. First, and perhaps most significant, the category clearly includes coercive sex, where the coercion is great enough to undercut full autonomy but is not great enough to vitiate consent. Coercive sex thus defined produces very real harms, and one of the clearest costs of the ethic of consent in the sexual realm is that those harms are "legitimated" by the ethic of consent. Some examples: sex given against the backdrop of a vague and unstated promise by a partner that although he could, he will not employ force, may be coercive, but it is also clearly not rape. It is consensual. ${ }^{39}$ Does that mean it confers value on both parties? And is

\footnotetext{
${ }^{37}$ See Susan Frelich Appleton, Toward a “Culturally Cliterate” Family Law? 23 BERKELEY J. GENDER, L. \& JUST. 267 (2008); Robin West, Consensual Sexual Dysphoria: A Challenge for Campus Life, 66 J.L. EDUC. 804 (2017); Shari Motro, Scholarship Against Desire, 27 YALE J.L. \& HUMAN. 115 (2015).

${ }^{38}$ E.g., Emily A. Ipett \& Letitia Anne Peplau, Why Some Women Consent to Unwanted Sex with a Dating Partner: Insights from Attachment Theory, 26 PsYCHOL. WOMEN Q. 360 (2002); Sarah J. Walker, When "No” Becomes "Yes": Why Girls and Women Consent to Unwanted Sex, 6 APPLIED \& PREVENTIVE PsyChOL. 157 (1997); Susan Sprecher et al., Token Resistance to Sexual Intercourse and Consent to Unwanted Sexual Intercourse: College Students' Dating Experience in Three Countries, 31 J. SEX RES. 125 (1994); Lucia F. O'Sullivan \& Elizabeth R. Allgeier, Feigning Sexual Desire: Consenting to Unwanted Sexual Activity in Heterosexual Dating Relationships, 35 J. SEX RES. 234 (1998); Charlene L. Muehlenhard \& Stephen W. Cook, Men's self-reports of unwanted sexual activity, 24 J. SEX RES. 58 (1988); Miriam Lewin, Unwanted Intercourse: The Difficulty of Saying No, 9 PSYCHOL. WoMEN Q. 184 (1995); Pamela I. Erickson \& Andrea J. Rapkin, Unwanted Sexual Experiences Among Middle and High School Youth, 12 J. Adolescent HeAlth 319 (1991). K.G. Santhya, Nicole Haberland, F. Ram, R.K. Sinha \& S.K. Mohanty, Consent and Coercion: Examining Unwanted Sex Among Married Young Women in India, 33 Int'l FAM. Plan. PERSP. 124 (2007).

${ }^{39}$ For force to vitiate consent to sex, the threat must be credible, as well as clearly stated and understood. Background conditions that render sex coercive do not suffice to render it nonconsensual. For a good discussion of
} 
it therefore something to applaud? Sex with one's husband or domestic partner in exchange for an expectation that money will be left on the kitchen counter for children's school lunches in the morning is broadly coercive, but also clearly consensual. The trade is of value to both parties, presumably. Is it therefore a good trade? Exchanges of sex for a placid home life, for a healthier because more pacific environment for oneself and one's children, or for the simple absence of a "foul mood" from a partner or spouse the following day might all be coerced, but they are also consensual. They are not assaultive. Likewise sex given to an undesired but safe man in exchange for his protection against the risk of violent sex that might be threatened by others is coerced but it too is not nonconsensual. The critical point here is that the consent that can precede all of this coerced sex in effect legitimates not only the coercive background conditions and the harms implicit in all of those background conditions - harms which I assume are selfevident -- but also the harms of trading sex to mitigate them: the harms of living in an environment in which one's own desires are not honored, in which one lacks the sovereign power to reserve one's sexual body for uses which will produce one's own pleasures, a world in which sex is a relief from oppression rather than a product of it.

Some academic feminists, including both Catharine MacKinnon ${ }^{40}$ and more recently the philosopher Scott Anderson, ${ }^{41}$ have urged in light of the harms of coerced but consensual sex that the definition of sexual assault should be widened so as to include coercive sex, rather than solely nonconsensual. For a number of reasons, this position has not taken hold, and the broad feminist consensus on the liberal reform position has remained: the criminality of sex should depend upon the absence of consent, and not the presence of coercion. ${ }^{42}$ Criminalizing coercive sex would simply sweep too broadly, and might also wrongly individualize what are better understood as social ills: the causes of coercion may well be societal, or communal, or historical, and not the pathologies or malignancy of particular perpetrators. I generally agree with this consensus. One consequence of it, however, is that the harms of coercive sex - sex that is coercive but also consensual, and therefore legal -- are legitimated. The harms of the sex that is the product of coercion, as well as to some degree the coercive conditions themselves, are shielded from moral critique, as well as from legal challenge. ${ }^{43}$

this limitation, as well as others, of consent-based accounts of rape, see Scott A. Anderson, Conceptualizing Rape as Coerced Sex, 127 ETHICS 50 (2016); Robin West, On Rape, Coercion and Consent, JOTWELL, Mar. 15, 2016 (reviewing Anderson, supra) https://juris.jotwell.com/on-rape-coercion-and-consent/

${ }^{40}$ MacKinnon, Rape Redefined, supra note 13.

${ }^{41}$ Scott A. Anderson, Conceptualizing Rape as Coerced Sex, 127 ETHICS 50 (2016); Robin West, On Rape, Coercion and Consent, JOTWELL, Mar. 15, 2016 (reviewing Anderson, supra) https://juris.jotwell.com/on-rapecoercion-and-consent/

${ }^{42}$ See, e.g., Deborah Turekheimer, Sexual Agency and the Unfinished Work of Rape Law Reform, in RESEARCH HANDBOOK ON FEMINIST JURISPRUDENCE (Robin West \& Cynthia Bowman eds., 2019); Michelle J. Anderson, Campus Sexual Assault Adjudication and Resistance to Reform, 125 Yale L.J. 1940 (2016); Michelle J. Anderson, Sex Education and Rape, 17 MiCH. J. GENDER \& L. 83 (2010); Michelle J. Anderson, Negotiating Sex, 78 S. Cal. L. Rev. 1401 (2005); SUSAN ESTRICH, REAL RAPE: HOW THE LEGAL SySTEM ViCTIMIZES WOMEN WHO SAY No (1988); Susan Estrich, Rape, 95 Yale L.J. 1087 (1986)e. But see Susan Brison, Justice and Gender-Based Violence, 67 REV. INT'L PHIL. 259 (2013).

43 One hidden cost of the ethic of consent is that it has led critics to adopt what I've called elsewhere a "coercion funnel:" wherever consent seemingly leads to bad outcomes, the critic is inclined to label the transaction coerced, precisely so as to avoid the legitimating implications of the ethic of consent. The coercion funnel is the flip side of 
It is not, however, only coercive consensual sex - whether coercive sex is identified as criminal or not - that is potentially harmful, and widely legitimated by the ethic of consent. Commodified sex is as well. Unwanted and un-pleasurable sex that is not nonconsensual and not coerced in any obvious or familiar manner, but which is nevertheless part of a trade, whether the trade is for money or for in-kind necessities, is all largely legitimated by the ethic of consent. Because it is so legitimated, like coerced sex, commodified sex is generally shielded from critique, as are the conditions that prompt the sale and attend it, including not only the poor work and health protections of sex workers, but also the poor life conditions of women world over who exchange sex for the possibility or promise of life itself. Broadly, the ethic of consent legitimates the harms incident to the commodification of sex, and the harms incident to the trades, whether the trades involve the exchange of sex for economic security, affection, status, physical protection, money, promises of various sorts, or other forms of in-kind compensation. It may well be unwise for a host of reasons to criminalize sex work, and it would of course be unwise to criminalize in-kind sexual trades. But here, as with coerced sex, note the side-effect of the laudable impulse to eschew reliance on criminal law for policing morality: the terms of those trades are insulated from political criticism, as well as from legal regulation, as consent legitimates both the practice and its terms.

Third: consent legitimates the possible harms of all of the consensual sex, worldwide, that is driven by a sense of duty rather than an expectation of pleasure, whether the duty is compelled by the tenets of a religious faith, by community, or by family or clan expectations. There is little to no discussion in scholarly literature, feminist or otherwise, of the harms that might befall women who over the course of an entire adult lifetime regularly submit to herterosex with a man they do not desire, from whom they receive no pleasure, and whom they may not have had a hand in choosing as a life partner, because of their subscription to a religious way of life that dictates as much. ${ }^{44}$ If the sex in such marriages is not rape, because it is broadly consensual, it is, by the dictates of the ethic of consent, not fit for critique, just as sex was once not fit for critique, or legal regulation, because it was marital. For many women the ethic of consent is thus doing the work once done by marital rape exemptions, wherever marriage rests on a religious world order that mandates female sexual submission within marriage to male partners.

Fourth: the ethic of consent legitimates the harms of what might best be called hierarchic sex in workplaces or schools that may well be desired or welcomed by both parties, and which is

the ethic of consent, and it is unfortunate for reasons that parallel the problems with the ethic of consent that precipitates it - the coercion funnel weakens critical vocabulary and imagination, and expands beyond usefulness the concepts of coercion and nonconsensuality both. It is particularly damaging, however, in the context of sexual ethics. Not all coerced sex is nonconsensual, and if consent is the dividing line between legal and illegal sex, then not all coerced sex is rape. We need to develop a vocabulary and a critical acumen regarding coercive sex that is distinctive from the ways in which we discuss nonconsensual sex, and we need to develop a discourse around the ways that law might sensibly respond to it, without imposing the hammer of the criminal law. See generally, Robin West, Sex, Law and Consent, in THE ETHICS OF CONSENT: THEORY AND PRACTICE (Alan Wertheimer and William Miller, eds. 2008).

\footnotetext{
44 The exception is Mary Becker, Women, Morality, and Sexual Orientation, 8 UCLA WoMEN's L.J. 165,199 (1998); Mary Becker, The Politics of Women's Wrongs and the Bill of "Rights", 59 U. CHI. L. REV. 453, 458-86 (1992); Mary Becker, Family Law in the Secular State and Restrictions on Same-Sex Marriage: Two are Better than One, 2001 U. ILL. L. REV. 1 (1999).
} 
accordingly neither assault nor harassment, but which might nevertheless be harmful. Sex between workers at grossly divergent levels in a workplace hierarchy -- such as a professor and a graduate student or a president and an intern - is not sexual harassment so long as it is welcome on all sides (as it was, for example, in the affair between Lewinski and Clinton). ${ }^{45}$ Yet, that sex might blunt workplace ambition when it occurs at work, and it might kill scholarly aspirations when it occurs between professors and students. Such sex is not rape and it is not harassment either, so long as it is fully welcomed, but it might nevertheless be plenty harmful. We should be discussing those harms, whether or not we are inclined to legally regulate them (which just to be clear I have elsewhere argued we should not). ${ }^{46}$

Fifth: consent legitimates a broad swath of sexual transactions, particularly on college campuses, that might be called "culturally mandated," by which I mean sex that is driven by the felt imperatives of a culturally dictated sexual ethic that requires participation in consensual sexual activity as a condition of deeply desired acceptance in a high status group. Hook-ups between near-strangers on college or high school or middle school campuses that are not desired, not enjoyed, not relished, and contain no pleasure for one or both parties, and which are driven not by lust but by a desire for recognition by the group, or by high status individuals within the group, might carry harms to the health, identity and integrity of participants. These harms, which over the last ten years have been the subject of some academic study, ${ }^{47}$ are beginning to become visible, as both campus efforts against sexual assault and the MeToo movement intensify, but they are also somewhat obscured by those movements: culturally mandated sex, as I'm defining it, is not rape, it is not assault, and it is not sexual harassment either, as it can be welcomed by both parties. Thus: requiring "affirmative consent," no matter how defined, rather than simple consent will not even begin to address the harms of culturally mandated sex on college and high school campuses; this sex is fully consensual. Nor will more vigilant enforcement of sexual harassment laws, or enhanced disciplinary control of sexual assault under Title IX. ${ }^{48}$ I will discuss these harms below, but again, my point here is that the harms of sex

\footnotetext{
45 There is a debate among feminists about whether schools should, as a matter of policy, police against such relationships. But they are not sexual harassment, so long as they are both consensual and mutually welcomed. See Robin West, Unwelcome Sex: Toward a Harm-Based Analysis, in NEW DIRECTIONS IN SEXUAL HARASSMENT LAW 138 (Catharine A. MacKinnon \& Reva B. Siegel eds., 2004); Deborah L. Rhode, Sex in Schools: Who's Minding the Adults?, in New Directions in SEXuAl Harassment LAw 20 (Catharine A. MacKinnon \& Reva B. Siegel eds., 2004); Pamela Y. Price, Eradicating Sexual Harassment in Education, in NEW DIRECTIONS IN SEXUAL HARASSMENT LAW 60 (Catharine A. MacKinnon \& Reva B. Siegel eds., 2004).
}

\footnotetext{
46 See Robin West, Unwelcome Sex: Toward a Harm-Based Analysis, in NEW DiRECTIONS IN SEXUAL HARASSMENT LAW 138 (Catharine A. MacKinnon \& Reva B. Siegel eds., 2004).

${ }^{47}$ For discussion of this literature, see West, Consensual Sexual Dysphoria, supra note 35, and authorities cited in notes 35 and 36 supra.

${ }^{48}$ Title IX of the Education Amendments of 1972, 20 U.S.C. $\S \S 1681-1688$ (2002). See generally Nancy Cantalupo, Masculinity \& Title IX: Bullying and Sexual Harassment of Boys in the American Liberal State, 73 Md. L. Rev. 887 (2013-2014); Nancy Cantalupo, For the Title IX Civil Rights Movement: Congratulations and Cautions, 125 Yale L.J. F. 281 (2016); Nancy Cantalupo, Title IX's Civil Rights Approach and the Criminal Justice System: Enabling Separate but Coordinated Parallel Proceedings, in THE CRISIS OF CAMPUS SEXUAL VIOLENCE: CRITICAL Perspectives on PREVEntion AND Response 125 (Sara Carrigan Wooten \& Roland W. Mitchell eds., 2015); Nancy Cantalupo, Institution-Specific Victimization Surveys: Addressing Legal and Practical Disincentives to Gender-Based Violence Reporting on College Campuses, 15 Trauma Violence Abuse 227 (2014); Nancy Cantalupo, “Decriminalizing” Campus Institutional Responses to Peer Sexual Violence, 38 J.C. \& U.L. 483 (2012).
} 
consequent to the hook-up culture on campuses are insulated from critique, and to some degree even from study, by the ethic of consent that shrouds them - and they are perversely all the more insulated, as efforts intensify to eradicate sexual assault. Worse, those consensual harms are insulated even from recognition by the women and girls, and the men and boys, that sustain them.

Sixth: the ethic of consent shields the possible harms of what some feminists now call "maintenance sex," meaning un-pleasurable and undesired sex offered in exchange for the maintenance of an emotionally sustaining relationship. ${ }^{49}$ Liberal and sex positive feminists may be right to note that these bargains are often sound, and that what is gained - a loving relationship - is often well worth what is lost, which may be minimal, or truly nothing at all. Giving sex to keep a loving relationship intact is, in short, a loving thing to do. The gauze, though, of consent, coupled with the trade's emotional payoff, shields the trade from any sort of critical examination: is that which is lost truly nothing? How do we know? The volatility of the issue reveals a lack of certainty, as the vehement discussions around them, and defenses of them, (on blogs) quite dramatically demonstrate. ${ }^{50}$

Lastly, consent legitimates the harms of consensual but recklessly un-contracepted sex, including, as discussed above, the harm entailed by the risk of pregnancy. ${ }^{51}$

All of this sex - coerced sex, commodified sex, dutiful sex, hierarchic sex, culturally mandated sex, maintenance sex and reckless uncontracepted sex - is consensual. All of it might also produce harms that should be named and confronted, and all of those harms, along with the sex itself, are to varying degrees veiled by the legitimating power of the consent that precedes it. Let me quickly make the causal connection, before turning to the harms. Start with coercive sex. It is not only liberals and liberal feminists that mask or obscure the harms of coercive sex. As noted above, Catharine MacKinnon has long argued that coercion, rather than consent, should be the demarcation between legal and criminal sex precisely because so much of what the law regards as consensual is felt by women as coerced - and therefore is felt to be nonconsensual, although understood by law to be consensual. Note, however, that this conflation does not elucidate the harms of consensual but coerced sex, rather, it erases the category. If all sex that is felt to be coerced is in fact nonconsensual, then there can hardly be a distinctive harm caused by consensual but coerced sex. We simply do not have a discourse, much less a debate, over either the law's treatment or the ethical status of coerced sex, despite its ubiquity and its self-evident harms. ${ }^{52}$

And what of commodified sex? Feminists have famously split on the wisdom of legalizing the sex trade, in part because of concerns regarding the labor conditions of sellers, and in part because of concerns over utilizing a broken criminal justice system to police against these harms or any others. ${ }^{53}$ The debate however has rarely addressed the harms of the

\footnotetext{
${ }^{49}$ See, e.g., Meghan Murphy, Interview: Dr Meagan Tyler, on The Way Sex Therapy Reinforces Compulsory Heterosexuality and How We Can Push Back, FEMINIST CURRENT (Mar. 4, 2018), https://www.feministcurrent.com/2018/03/04/interview-dr-meagan-tyler-way-sex-therapy-reinforces-compulsoryheterosexuality-can-push-back/.

${ }^{50}$ Tracy Moore, How to Have Maintenance Sex, JEZEBEL (Jan. 5, 2015), https://jezebel.com/how-to-havemaintenance-sex-1677160234.

${ }^{51}$ West, Hobby Lobby, supra note 11.

52 I elaborate on this argument in Robin West, Sex, Law and Consent, in THE ETHICS OF CONSENT: THEORY AND PRACTICE (Alan Wertheimer and William Miller eds., 2008).

53 See, e.g., Notes: Should Prostitution Really Be a Crime?, The ATLANTIC,
} 
commodification of sex itself, rather, it has focused on the apparent lack of autonomy of sex workers: feminists attuned to the harms of the sex trade characterize participants as coerced, others characterize them as autonomous agents. More broadly, plenty of feminists, as well as non-feminists, have worried that in-kind sexual trades - sex for sustenance, for support, for food, for drugs, for a job, for a promotion, or for a high grade in a class -- and whether between married partners, cohabitators or strangers, should be subjected to criticism. But here as well a direct focus on the harms that might be occasioned by unwelcome sex traded for other goods has not been the focus. The focus has instead been on the quasi-coercive nature of the transaction, either because the parties have radically divergent degrees of power or the woman trading sex for goods is herself so disempowered as to have few other choices. The focus on unequal power here as elsewhere casts the net far too broadly - every sexual exchange, like every non-sexual exchange, involves parties with different degrees of power. It also casts the wrong net. Sex between parties with different amounts or configurations of power is not inherently problematic. It is sex that harms that should be the focus, not sex between differently empowered partners. Sex that is commodified and given in exchange for non-sexual goods, even if between people with relatively equal power, might be harmful. A focus on the unequal bargaining power of the sex worker and her customer will not elucidate what those harms might be.

More quickly, "hierachic sex" at work or school has now been the subject of political critique and to a lesser degree academic writing for at least three decades, but here as well, the debate has focused on whether to characterize that sex as coerced, and therefore nonconsensual, and therefore a form of sexual harassment, rather than on the harms it might occasion, assuming it to be consensual. ${ }^{54}$ Similarly feminists who address maintenance sex, mostly on blogs, and who argue against it, typically do so on the grounds that it reflects disempowerment, rather than on the basis of its harms. ${ }^{55}$ In all of these cases the focus is overwhelmingly on whether or not the characterization of the sex as consensual is mistaken, and on whether the woman who gives it is agentic. The felt harms of all of that coercive, hierarchic, commodified, culturally mandatory, or duty driven sex however - whether or not the woman consenting is agentic -- are rarely delineated. That they are not, is at least in part a function of the wide embrace of the ethic of consent.

So, what are these harms? Some of the psychological harms occasioned by the acquiescence in unwanted but consensual sex - what I called above unwanted culturally prescribed sex, particularly among college students - as noted above, are now being studied by a handful of social scientists, including academic sociologists, social workers, and mental health professionals. ${ }^{56}$ The endurance of at least this form of consensual but unwanted sex, according to a number of recent studies over the last decade, can bring on depression, a feeling of a lack of

https://www.theatlantic.com/notes/2016/02/the-divide-over-prostitution-on-the-feminist-left/471168/. See also MacKinnon, Rape Redefined, supra note 13, at 443.

${ }^{54}$ See Robin West, Unwelcome Sex: Toward a Harm Based Analysis, in NEW DIRECTIONS IN SEXUAL HARASSMENT LAW (Catherine MacKinnon and Reva Siegal eds., 2003).

${ }^{55}$ See, e.g., Lois Shearing, Why Maintenance Sex is Bullshit, Medium Corporation, available at: https://medium.com > why-maintenance-sex-is-bullshit-d5d72347d90d

\footnotetext{
${ }^{56}$ See authorities cited in notes 35 and 36 supra.
} 
control, a diminution in felt autonomy and self-regard, and a host of related psychic ills. It also has been shown to correlate with failures to employ birth control, so it heightens the risks of unintentional pregnancies. I have suggested elsewhere that there may be other harms, however, not so easily captured, of consensual unwanted sex across the board. ${ }^{57} \mathrm{~A}$ woman or girl who consistently consents to unwelcome and unwanted sex, whether out of a sense of religious or role-defined duty, subtle coercion, or as part of a trade, undermines her own physical integrity as she compromises her body's physical boundaries for reasons unrelated to her own pleasure. ${ }^{58}$ There may be a psychic violation as well: A woman who engages in unwelcome sex likewise compromises her sense of and possession of her own sovereignty, as she uses, exposes, and gives over her body in a way that is in service to the ends of another, rather than to her own ends. And, there may be a moral harm to character: she compromises her moral integrity when and if she lies about her enjoyment of it later. These harm to physical, psychic and moral integrity can in turn cause what we might think of as political harms: a woman or girl, or man or boy, abridges her autonomy, when she subjects her body to physical activity toward the end of servicing another.

In part because of the \#MeToo movement, some of the psychological harms, and even some of the political harms, of consensual but unwanted sex have become the subject of recent blog and journal writing, as well as the subject of debate in the pages of The New Yorker, The Atlantic, and elsewhere. ${ }^{59}$ Making a habit of consenting to unwanted sex, can lead to habits of self-denigration or political devaluation, which carries its own costs, particularly in a liberal society that not only values but also broadly assumes the pursuit of rational self-interest. A woman or girl in the habit of putting her physical body to the service of the interests, desires and preferences of another, rather than herself, might find herself compromised in her ability to use her body and abilities in non-sexual contexts to maximize her own interests and satisfy her own preferences. The habit of self-denigration in other words might "bleed over." It might not be surprising, for example, that many girls and women, as well as some men and boys, who habitually surrender their bodies for the sexual use of others, might likewise have a difficult time raising their hands in a law school classroom, ${ }^{60}$ or negotiating the price of a new car in a

\footnotetext{
${ }^{57}$ Robin West, The Harms of Consensual Sex, in ThE PHILOSOPHY OF SEX: CONTEMPORARY READINGS 317 (Alan Soble ed. 2002); West, Consensual Sexual Dysphoria, supra note 35; West, Sex, Law and Consent, supra note 48. 58 The violation of the boundary of the body is just not understood broadly as a harm when the person suffering it is female and the nature of the violation is sexual. Women's bodies are regarded as porous, and that degree is substantial. Andrea Dworkin's account of this harm in her book Intercourse is chilling, and in some circles at least justly famous. ANDREA DWORKIN, INTERCOURSE (1987).
}

${ }^{59}$ Katie Way, I Went on a Date with Aziz Ansara. It Turned into the Worst Night of My Life, Babe (April 2017); Kristen Roupenian, Cat Person, New YoRKER, (Dec. 2017); West, Manufacturing Consent, supra note 58.

60 There is now a sizeable literature on the differences between women's experiences of law school and men's, from the 1970s to the present, part of which focuses on these differences in participation rates. See, e.g., Taunya Lovell Banks, Gender Bias in the Classroom, 38 J. LEGAL EDUC. 137 (1988) (reporting on empirical study of among other differences, patterns of participation in the classroom);For studies that are school specific, see, e.g., WORKING GROUP ON STUDENT EXPERIENCES, HARVARD LAW SCH. STUDY ON WOMEN'S EXPERIENCES AT HARVARD LAW SCHOOL (Feb. 2004), Allison L. Bowers, Women at the University of Texas School of Law: A Call for Action, 9 TEX. J. Women AND LAw 117 (2000); Celestial S.D. Cassman \& Lisa R. Pruitt, A Kinder, Gentler Law School? Race, Ethnicity, Gender, and Legal Education at King Hall, 38 U. C. DAVIS L. REV. 1209 (2005); Marsha Garrison et al., Succeeding in Law School: A Comparison of Women's Experiences at Brooklyn Law School and the University of Pennsylvania, 3 Mich. J. GENDER AND LAW 515 (1996); Joan M. Krauskopf, Touching the Elephant: Perceptions of Gender Issues in Nine Law Schools, 44 J. LEGAL ED, 311, 314 (1994). For what may be the most extensive empirical study, see Lani Guinier et al., Becoming Gentlemen: Women's Experiences at One Ivy League Law School, 143 U. 
favorable direction, ${ }^{61}$ or bargaining themselves a wage increase. ${ }^{62}$ These political harms, if they exist, are rendered invisible, or even oxymoronic, by virtue of the legitimating function of the ethic of consent. Again, the consensuality of the sex that causes them veils the possibility of harm.

There is another possible harm, though, that may be more pervasive than either the measurable psychological harms or the speculative political ones mentioned above, that might attend to the sufferance of all the forms of unwanted consensual sex noted above, and that is not only legitimated by the ethic of consent, but also caused by it. A woman, girl, man or boy who consents to sex she does not welcome, want, or desire, and from which she derives no pleasure, may do so for any number of reasons, as catalogued above: she may do so to ward off the danger of future violence from her partner or from others. A mother may do so to ensure the continuing support for her children's needs. A girl or boy, woman, or man, may do so to hold at bay a foul mood from a boyfriend or girlfriend the next day. Anyone may do so in exchange for money or in kind compensation. Many women world-wide consent to sex they don't want or welcome because they view it correctly as a part of their marital duty according to the dictates of their faith. A teenaged girl or boy may do so because of peer pressure, or to win the attention of a high-status boy, woman or man. All of this consensual sex might be coercive, or commodified, or dutiful, or peer pressured, and so on, as described above. What I want to stress here is that most of it is also unwelcome, unwanted, not desired, and not enjoyed. Consent is given without any expectation of pleasure, and that expectation is borne out.

When that happens, there is, I suggest, a rupture between the phenomenological experience of sexual intimacy, and the most basic assumption of the ethic of consent in the context of sex, that consensual transactions are mutually pleasurable, and that their value inheres in that fact. That rupture might itself be harmful, and if it is, it is entirely unstudied and largely unnamed. I propose to label the harm that may be caused by the rupture between consensual but unwanted and unpleasurable sex, and the social and cultural expectation that consensual sex is mutually beneficial precisely because it is mutually pleasurable, "hedonic sexual dysphoria." By the phrase, I mean to refer to the felt rupture between one's understanding of what is or should be in one's sexual interests, and one's own hedonic experiences of physical pain and pleasure.

"Hedonic dysphoria" more generally - understood as a rupture between one's hedonic experiences and the expectations defined by the ethic of consent - can occur in realms other than the sexual. ${ }^{63}$ It might be most acute, however, in sexual life. In a world in which the ethic of consent holds a firm grip on our understanding of the way we interact with each other and our natural environment, and in which the law and ethics of sexuality has moved so inexorably toward that ethic, the risk of consensual dysphoria becoming an entrenched feature of our sexual

\footnotetext{
PA. L. REV. 1, 2 (1994). Yale law students have been particularly forthcoming about their experiences. For early explorations of women at Yale Law School, see Catherine Weiss \& Louise Melling, The Legal Education of Twenty Women, 40 StAN. L. REV. 1299 (1988). For descriptions of the experiences of women at Yale in the nineties, see Paula Gaber, Just Trying to Be Human in This Place: The Legal Education of Twenty Women, 10 YALE J.L. \& FEMINISM 165, (1998), and for an account of women law students at Yale in the aughts, see Sari Bashi and Maryana Iskander, Why Legal Education is Failing Women, 18 YALE J.L. \& FEMINISM 389 (2006).

${ }^{61}$ See generally Ian Ayres \& Peter Siegelman, Race and Gender in Bargaining for a New Car, 85 AM. ECON. REV. 304 (1995).

${ }^{62}$ See generally Carol M. Rose, Women and Property: Gaining and Losing Ground, 78 VA. L. REV. 421 (1992).

63 See Robin West, Bartleby's Consensual Dysphoria, in POWER, PROSE AND PURSE: LAW, LITERATURE AND ECONOMIC TRANSFORMATIONS, (Saul Levmore, Martha Nussbaum, and Alison LaCroix, eds., 2019).
} 
lives, I believe, is high. The harms it might cause are also almost impossible to even assert, much less describe, given the ethic of consent.

To see why, go back to that ethic's logic. A consensual transaction, presumptively, brings into being an improved world over the pre-consensual transaction, assuming no negative third party affects, simply because of its consensuality: the world is richer, more efficient, and freer post-consent. Thus, a consensual exchange of money for a product on an open market - a trade to which both parties consent - presumably brings into being a better world than the world prior to the trade, by virtue of the mutual consent of the seller and buyer: the seller has something - money - he values more than he valued that which he sold and the buyer likewise has something she values more than the money she relinquished for it. The post-sex world where both parties have consented can be modeled on this understanding. It is presumptively better than the pre-sex world, solely by virtue of the presence of consent of both parties. Again, legitimation critiques like those offered by critical scholars and reviewed above have provided some reason to be skeptical generally of the gains to be had from consensual trades in markets for goods and services, and arguments offered by feminists have suggested reasons to rethink that belief in the area of sexual ethics. The harms legitimated in our commercial as well as work worlds, as well as in our sexual worlds, might at least on occasion outweigh some of the gains garnered through the trades themselves.

There is however a more specific claim intrinsic to the ethic of consent, or implied by it. It is not only "the world" abstractly considered, that is presumed to be improved by virtue of the consensual trade. More concretely, the individual who renders that consent is presumed to be subjectively happier, or sated, or more content, or more fulfilled after the consensual act than prior. The maximization of consensual transactions, whether on exchange markets for consumer goods or in intimate life for sexual satisfaction, presumptively contributes to the overall subjective happiness of individuals free to engage in them. What kind of claim is this? It might be definitional. But I think more is typically meant. If the claim that consensual transactions increase subjective happiness is not simply tautological, then it is a general and empirical claim about our subjective lives. ${ }^{64}$ And as such, it might on occasion not be true. What happens when it isn't true, particularly where we also believe it to always be true? Here's one possibility: When it isn't true, to the degree that the ethic of consent has taken hold as an article of faith about the way the world is constructed, then the result is a divergence, or cleavage, between the person's belief that her consent implies that that to which she consented has made her happier, or more contented, or more sated, or more satisfied, and her subjective experience of not experiencing any such increase, of being more rather than less miserable after the consensual transaction than before. That divergence between a belief about one's own subjective experience - I must be happier because I consented to this - and the experience itself -I'm more miserable than I was prior to this event to which I've consented - is what I call hedonic dysphoria: a jarring experience of a disconnect between one's beliefs about the way one should be experiencing the world and the way one is in fact experiencing it. That dysphoria can be psychologically

\footnotetext{
${ }^{64}$ I address this understanding of Posner's defense of the political morality of wealth maximization in detail in Robin West, Authority, Autonomy and Choice: The Role of Consent in the Moral and Political Visions of Franz Kafka and Richard Posner, 99 HARV. L. REV. 384 (1986) available at: http://scholarship.law.georgetown.edu/facpub/489 http://ssrn.com/abstract=1737920.
} 
debilitating. It can also be politically disabling. It may well be pervasive in commercial and work life. But it might be most profound, most damaging, and most ubiquitous, in contemporary sexual life.

If it is, then it makes sense to think of or characterize hedonic dysphoria as a direct consequence of the ethic of consent as well as a part of what is broadly legitimated by the ethic of consent, and its broad contemporary embrace in sexual life. The ethic of consent teaches that that to which we consent makes us happier, more satisfied, or more sated. If that to which we consent instead leaves us frustrated and dissatisfied, and we cannot dislodge even in our own minds the ethic of consent as expressive of a true relation between consent and happiness, then we might come to distrust the teaching of our own experiences. When the experience involved is sexual, then the distrust is of not just "experience" but the experiences of one's own physical body, and more specifically, of one's own hedonic self. The result is a psychic and a physical gaslighting, which is then broadly legitimated by the same ethic of consent which causes it: the gaslighting itself is a part of that to which consent is given, a part of that which is legal by virtue of consent, a part of that which the ethic is not only causing but as it does so, simultaneously veiling and denying.

To the list of the types of harms occasioned by consensual sex and legitimated by the consent that precedes it, I would add the possibility of hedonic dysphoria. How pervasive is it, and how harmful? As suggested above, women and girls may consent to un-pleasurable sex they do not desire or welcome for all sorts of self-serving reasons, ranging from a justified fear of potential but future violence, a sense of duty, an awareness of community expectation that they satisfy a man, an expectation of profit, or peer pressure. They also may consent, however, because they have been repeatedly told, and they have come to believe, that sex is intrinsically pleasurable or desirable, so long as it is consensual. When they do so, they may harbor the belief, instilled by round the clock advertising, the messaging of soft pornography, depictions of consensual sex in popular entertainment, some forms of liberal sex education, and the sex positive ethos of high school and college culture, that sex, if consensual, is pleasurable. If it was in fact not, then a woman or man who experiences it as not, faces the possibility not just of "regret," but of a lack of alignment between the experiences of their physical selves, and the societal expectation of the nature of that experience. This presumptively pleasurable transaction was painful, invasive or boring. Anyone in that position can either begin to challenge the teaching of their culture, peers, religion, community, parents, family, and school, or they can deny the teaching of their bodies.

How many girls, women, boys and men do the latter? And what does that entail? Partly, it entails denying the significance of one's own pleasures and pains, and their connection to preference, choice, and action. And once that happens, it likewise entails breaking the psychic connection, central to liberal ideology, between pain and pleasure, on the one hand, and preference, choice and action on the other, where consent is the behavior that effectuates that denial. When engagement in consensual but un-pleasurable and undesired sex becomes habitual, then one has entered a habitual state in which one's own pain or pleasure does not direct one's preferences or decisions regarding the use of one's body and access to one's sexual body. One's own pain or pleasure is de minimus in importance. And, one's own body no longer instructs: it provides no hedonic guidance, much less the kind of natural imperative on which Jeremy Bentham once so vigorously insisted: ${ }^{65}$ In a state of hedonic dysphoria, one does not recoil from

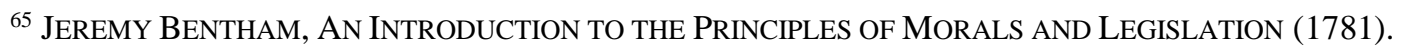


pain or feel drawn to pleasure as he claimed we all do, all the time. In a state of specifically sexual hedonic dysphoria, pleasure and pain matter only a little or not at all, with respect to intimate physicality. This may also spill-over effects: hedonic dysphoria entails maximally denying not only the significance but perhaps the reality of one's own pleasures and pains. Those pleasures or pains just don't exist, we may well come to believe, if they don't track the cultural script.

The pervasive impact of the ethic of consent in political, legal and cultural life is not the only reason the harms of hedonic dysphoria are hard to see, and hard to describe, when seen. A sexual libertarian and sex positive culture, in which sex is believed to purify almost whatever it touches of any capacity for harm, is a second. ${ }^{66}$ Consensual sexual harms are doubly masked: first by the ethic of consent, which defines them away, and second by a sex positive ethos, which creates a presumption against their seriousness, and possibly their occurrence. They are also clouded by liberalism per se, and its chronic failures to see the political dimension of private abuses of power. The ethic of consent itself, however, is what most directly implies the diminishment of the significance of interiority central to sexual dysphoria. It teaches us to flirt with our own physical debasement.

\section{Some Conclusions: On Consent, Desire, Pleasure, and Law}

To sum up: unlike other civil rights, the sexual and reproductive civil rights fought for and won in the last third of the twentieth century have been understood almost exclusively in Mainean terms. What civil rights confer, in these areas of life, are rights to give or withhold consent: to say no to sex, to abort a pregnancy, to choose not to conceive, to choose not to parent, to decide against maternity. I've argued thus far that while the value of those rights to withhold consent to our lives is great, the ethic of consent which grounds them carries risk: we habitually over-value the transactions to which we consent. In reproductive and sexual life, as in other areas of life, we wrongly imply from the necessity of consent to both the legality of sex and the obligations of pregnancy, that the sex or pregnancies to which we consent are good. There are costs in that over-valuation, which I've tried to spell out above.

If we drop the reductive equivalence of sexual and reproductive civil rights with the ethic of consent, I believe that we can imagine or reimagine civil rights in the areas of reproduction and sexuality both, that would better serve the animating purposes of civil rights law, as classically understood: inclusion in civil society, through the equal protection of ordinary civil laws. What would civil rights thus understood mean, in the context of our reproductive and sexual lives? A full panoply of reproductive civil rights should include not only rights to birth control and abortion services - not only rights to consent or withhold consent to pregnancy and maternity -- but also caregiver rights which would insure conditions minimal to individual flourishing and civic inclusion, where a pregnancy is taken to term. ${ }^{67}$ Caregiving is necessary human work, of value to the community, and intensely desired by most people that engage in it. As presently constituted it carries pervasive risks of impoverishment and isolation, both of which undercut flourishing and civil engagement both. A full understanding of civil rights should include a civil right to give care without risking impoverishment, and therefore a civil right to the legal infrastructure designed to accommodate a full reentrance into public life when the needs of dependents permit it, thus countering the risks of economic impoverishment and isolation that

\footnotetext{
${ }^{66}$ For a fuller discussion of the gloss of legitimacy conferred by sex positivism, see Robin West, Desperately Seeking a Moralist, 29 HARV. J. OF LAW AND GENDER, 1 (2006).

${ }^{67}$ See West, Do We Have a Right to Care? supra note 26.
} 
attend to maternity. Our rights, secured by ordinary law, should support caregivers who take leave from employment, and should compensate unemployed new parents at a dignified level until market work is feasible. And, they should provide a path back into public life of political participation, education, or employment, when the most labor-intensive parts of the reproductive cycle have ended.

In sexual life we might consider positing, and then acting on, a civil right to be free of unwelcome sex, alongside our legal right to be free of nonconsensual sex. Such a right would be an expansion, at least along one dimension, of a civil right we already enjoy: the right we have, under sexual harassment law, to be free of unwelcome sex in school or work that interferes with the harassed party's right to equal employment or education, and therefore with her equality. ${ }^{68}$ But unwelcome sex does not happen exclusively or even primarily at work or school. And, unwelcome sex outside of work and school is both harmful and ubiquitous: it interferes with a woman's, or girl's, or boy's, or man's, physical sovereignty, moral integrity, and autonomy. Indulged over time, and particularly over the course of a life time, it is likely to interfere with a woman's or man's flourishing, as well as with her psychic capacity, and possibly her physical capacity, to engage in civic life. We should have a civil right to be free of it.

What might a civil right to be free of unwelcome sex across the board, and not just at work or school, look like, and what would be the role of law in its construction? What would law have to do with it? A civil right to be free of unwelcome sex, beyond school and work, might in some cases be legally enforceable in private law suits, grounded in tort law, against perpetrators. Coercive but consensual sex, for example, could be understood as a civil wrong, and one that could give rise to a civil law suit. A civil right to be free of unwelcome sex could also mean, though, that we should embrace a moral duty and a political imperative to attend to its causes, with an eye toward using law and politics both to eradicate or at least ameliorate those conditions. If so, it would track the logic of legitimation critiques quite broadly.

Demonstrations of the legitimation harms intrinsic to the ethic of consent in commercial and labor markets are typically not aimed at curtailing the operation of consent in those markets. They're aimed at illuminating the background conditions that make the trades to which consent is given so coercive. The same should be true here.

A civil right to be free of unwelcome sex might rest on law only indirectly, and might require not so much a civil action as a civil education: minimally, sex education that would emphasize the difference between legal sex and good sex, and that would emphasize the reasons - whether stemming from the teachings of high mid or low brow culture, pornography, religious texts, or politically liberatory movements themselves - that have obscured that simple reality. The lesson is not complicated: for sex to be good -- both morally and hedonically -- it must not only be consensual, it must be wanted and welcomed by both or all parties. I do not see why this should not be a mandatory part of sex education courses and campaigns. "Don't have sex unless both parties want it." That's a simple but significant change to the familiar liberal bromide not to have sex unless both parties consent. It might also mean attending to the messaging of pornography, regardless of whether we wish or are capable of censoring it, and taking a conscious attempt to counter it where necessary: "The message central to so much pornography, that all women and all men desire and enjoy sex all the time, is not true." Our current love affair with consensual sex, like our love for consensual maternity, blinds us to the harms of both. As with the ethic of consent in other parts of our lives, it blinds us to the

${ }^{68}$ For critique see Mary Anne Franks, Sexual Harassment 2.0, 71 MD. L. REV. 655 (2012). 
constructive uses not only of law and legal discourse, but also of civil rights and civil rights discourse to address the harms of social life. 